\title{
Konflikt v hlasování Poslanecké sněmovny PČR (1993-2013)
}

\author{
Adversary Voting in the Czech Chamber of Deputies (1993-2013)
}

\author{
PETR DVOŘÁK ${ }^{1}$
}

\begin{abstract}
The paper explores the legislative unity of government and opposition blocs in the Czech Chamber of Deputies over a period of twenty years. As voting unity is usually rather low in the Czech Republic, temporarily high concentrations of the respective blocks'votes are linked to higher rates of conflict between the government and opposition. I use the Rice and UNITY indices to compare average unity scores of individual cabinets and also explorative time series of unity vectors in order to analyse bloc concentration, success rate, and increased conflict. The outcomes are relevant as both a case study and a methodological observation: (1) Broad differences in the logic of interaction are confirmed (e.g. caretaker cabinets show less conflict than standard cabinets). Although no universal trend (e.g. a transition from consensual to conflictual practice) is found, the Crech opposition became more concentrated and resorted to the tactics of serial blocking in the second decade; thus, a major change of behaviour occurred after all. (2) The Rice and UNITY indices correlate considerably; UNITY's discrimination capacity is not distorted significantly despite the nature of equilibria in the Chamber. Moreover; the UNITY index is able easily to distinguish contested votes which are not detectable by the Rice index alone.
\end{abstract}

Keywords: Government-opposition Relations, Party Government, Government Dominance, Parliament Voting, Coalition Unity, Czech Republic

\section{1. Úvod}

Tato studie se snaží uchopit a systematizovat základní vývoj vztahu mezi vládou a opozicí na půdě Poslanecké sněmovny Parlamentu Ceské republiky za dobu

\footnotetext{
1 Interní doktorand, Katedra politologie, Fakulta sociálních studií, Masarykova univerzita. Zaměřuje se na výzkum evoluce zastupitelské demokracie a na komparaci politických institucí. Kontakt: Katedra politologie FSS MU, Joštova 10, 60200 Brno, Česká republika / Czech Republic. E-mail: pdvorak@fss.muni.cz. Text byl zpracován v rámci projektu specifického výzkumu Katedry politologie FSS MU „Aktuální problémy politologického výzkumu" (kód MUNI/A/1342/2014).
} 
dvaceti let. Kritériem srovnání je míra konkurence (konfliktní interakce v porovnání s konsensuálnî) při hlasování mezi těmito dvěma bloky. Vzhledem k moderní historii státu (demokratická tranzice zahájená na přelomu osmdesátých a devadesátých let 20. století a následné budování demokratických institucî) donedávna existoval logický předpoklad postupného vývoje stranického systému, vládně-opozičních vztahů a vůbec celého českého politického systému, at' už ve smyslu ustálení pravidel hry (srov. např. Mansfeldová 2005; Lyons a Lacina 2009 aj.) nebo ve smyslu proměny dílčích oblastí politiky ve smyslu politics (např̀ parlamentní kultury a využívání parlamentních nástrojů; Wintr 2010). Předkládaný text si v této souvislosti pokládá otázku, zda je vývoj fungování jádra českých politických institucí tak znatelný, aby jej šlo zachytit i pomocí kvantitativního zkoumání, konkrétně deskriptivní analýzy dat z hlasovacího systému, potažmo zda lze změnu fungování vztahů mezi vládou a opozicí označit za postupnou nebo náhlou. Za tímto účelem se práce pokouší využít a porovnat dva ukazatele jednoty hlasování - Riceův index (Rice 1925) a index UNITY Johna Careyho (Carey 2000; 2007; 2009) - a dále vlastní výzkumný rámec na těchto ukazatelích založený.

Obvyklým cílem obdobných analýz je klasifikace, vizualizace systematické zařazení demokratických režimů a jejich vlastností (srov. Munck 2009: 1). Jedním z modelů pro komparaci demokracií a zároveň možným teoretickým východiskem výzkumu politického konfliktu je debata o westminsterském a konsensuálním modelu demokracie, jejímž klasikem je Arend Lijphart (1984; 1999). Ten se svého času pokoušel o umístění politických systémů na pomyslnou osu podle způsobu vládnutí (westminsterské demokracie ztělesňovaly princip soutěže, konsensuální princip kompromisu). Pokud poněkud zanedbáme komplexitu Lijphartova modelu a budeme-li se soustředit na primární kritérium soutěže, resp. spolupráce, můžeme prohlásit, že většina současných parlamentních demokracií, zejména těch evropských, jsou vzdáleny westminsterské praxi a převažuje v nich model skrytého, neprrímého politického konfliktu. Ten se vyznačuje mezistranickým vyjednáváním a kompromisy, ale také menší transparentností a sníženou možností vést strany $\mathrm{k}$ politické zodpovědnosti (Stokes 1999). Česká republika v tomto ohledu není výjimkou.

Jak ale uchopit proměnu vnitřní situace a dynamický vývoj, který systém prodělává $\mathrm{v}$ čase? Je obvyklé, že studie demokratických institucí jsou založeny na srovnávání vysoce agregovaných veličin a pracují téměř vždy s dlouhodobými a průměrnými hodnotami. Množství detailů se tak ztrácí a používání širokých kategorií svádí $\mathrm{k}$ tomu, že tyto instituce vnímáme velmi zjednodušeně. Lze však předpokládat, že tvorba ekvilibrií (stabilních situacî) mezi vládou a opozicí je $\mathrm{v}$ rámci institucionálního rámce dynamická - situace se proměňuje. V českém př́padě se nabízí „stabilizační hypotéza o přechodu od konsensuální praxe raných devadesátých let po více konfliktní charakter vládnutí, přechod k logice dvou bloků a celkové prohloubení vládně-opozičního konfliktu na konci první dekády jednadvacátého století, jak svého času hojně naznačovali (nejen) opoziční 
aktéŕi a jak by vyplývalo z předpokladu o ustalování demokratických pravidel hry. Jinými slovy: Můžeme prohlásit, že se čeští političtí aktéři chovají konfliktněji než dř́v?

Tato studie proto přistupuje $\mathrm{k}$ explorativnímu srovnání funkčních období dosavadních českých vládních kabinetů a pokouší se identifikovat rozdíly v logice interakce mezi vládními a opozičními stranami, popř́padě testovat hypotézu o celkovém trendu, který lze v České republice očekávat. Předmětem zkoumání je behaviorální aspekt konkurence, tj. nikoli změny ve vzájemném postavení institucí, aktualizace jednacích řádů apod., ale naopak obsah, který si v rámci politického systému vytvářejí političtí aktéŕi - konkrétně viditelná míra konfliktu vládněopozičního sporu o status quo v parlamentu, jenž je přirozeným centrem parlamentní demokracie. Konfliktnost v parlamentu lze operacionalizovat jako hlasování pro opačné možnosti spojené s vysokou jednotou hlasování. Takto postavená analýza je orientovaná na diachronní komparaci jednoho př́padu a je funkční pouze tehdy, pokud je obvyklé nasazení stran při hlasování omezené, tj. pokud nehlasují neustále jednotně - v českém př́padě ale toto „nebezpečí“ rozhodně nehrozí, protože stranické kluby mimo klíčových hlasování obvykle nevyužívají všech svých členů (tj. operují jen s částí svého hlasovacího potenciálu). Protože je zajištění jednoty na koaliční (a tím spíše opoziční) úrovni nákladné a strany $\mathrm{k}$ němu přistoupí spíše tehdy, budou-li motivovány důležitostí daného hlasování a snahou porazit politické soupeře, relativně vysoká jednota hlasování pro protichůdné možnosti (logika „hry s nulovým součtem“) ukazuje na důležité a zároveň konfliktní hlasování, které se vymyká běžnému parlamentnímu provozu (čím více takto vypjatých hlasování nacházíme, tím je interakce logicky konfliktnějšî). To potvrzuje nejen pozorování každodenní práce Sněmovny, ale i předběžný výzkum dat.

Platí, že jedním z hlavních problémů ve výzkumu demokracie a jejích kvalit je operacionalizace a metodologická práce vůbec: Problémem zde není nedostatek teorií a konceptů, ale spíše nemožnost či neochota existující koncepty uchopit a aplikovat (srov. Giebler 2012). Tato studie je explorativního charakteru a usiluje primárně o propojení a rozšíření perspektiv: Základním přínosem textu oproti dříve publikovaným výsledkům je zaměření na celkovou logiku fungování jádra politického systému (oproti studiím dílčích fenoménů, např. analýzy parlamentní kultury nebo analýzy hlasování o rozpočtu) spojené zároveň s neméně silným důrazem na výzkum neagregovaných dat, tj. s pokusem o zachycení časového, evolučního hlediska: Oproti studiím zabývajícím se celkovými, průměrnými výsledky podle logiky ,jeden systém - jeden př́pad“ text vychází z implicitních i explicitních předpokladů postupného vývoje demokratického režimu. Text se tedy pokouší odpovědět na četné požadavky, že je třeba nejen pracovat s existující teorií, ale i prrekročit rámec standardních zjednodušujících kategorií a zaměřit se na jemnější rozdíly na jednotlivých úrovních (srov. Munck 2009: 30-35, 40-41). Pokud je mi známo, tento typ studie v České republice zatím nebyl uplatněn. 
Druhotným výstupem takto definovaného výzkumného rámce je rozpoznání důležitých hlasování (těch, na kterých se bloky profilovaly a kvůli kterým investovaly náklady do zajištění jednoty). Lze tak identifikovat klíčová témata a jejich rozložení v legislativní agendě v rámci období. Poslední aspekt textu je metodologický - studie je zároveň pokusem o praktické použití a testování nepř́liš využívaného indexu UNITY ve specifických českých podmínkách.

\section{Teoretická východiska}

\section{a. Modely vládnutí}

Parlament představuje nejdůležitější instituci parlamentních demokracií ve smyslu legitimity, kontroly a celkové reprezentace politických preferencí, protože se zde odehrává střet mezi demokraticky ustanovenou vládou a parlamentní opozicí o status quo. Vládní a opoziční blok jsou klíčové síly, které nepř́mo reprezentují odlišné, byt' vysoce agregované společenské preference. Parlament je místem, kde se nejznatelněji protínají jednotlivé podoby odpovědnosti politického systému, tj. odpovědnost vertikální (čili vztah mezi voliči a politickými institucemi) a odpovědnost horizontální, resp. inter-institucionální (tedy vztah mezi institucemi navzájem; O’Donnell 1991). Předpokládá se, že politické strany ve volbách nabízejí odlišné vize, v politické debatě reprezentují odlišné preference a že se ve volbách nevyhýbají odpovědnosti skládat účty za svůj dosavadní výkon. Jelikož v parlamentní demokracii tvoř́ vláda a ,její“ parlamentní většina nejčastěji fúzní exekutivně-legislativní politické centrum, sledování prostředků, které má k dispozici parlamentní opozice pro vyvažování moci vlády je jedním z nejjednodušších způsobů, jak rozlišovat demokratické systémy podle horizontální odpovědnosti (Fortes a Brihuega 2012: 500).

Předobrazem parlamentní demokracie je ideální westminsterský model, který se vyznačuje existencí dvou silných stran a zpravidla vytváří podmínky pro vznik silných, výrazně dominujících jednobarevných vlád, a tedy i silné, relativně silně institucionalizované opozice. Výhodou takto nastaveného systému je snadné určení odpovědnosti za politická rozhodnutí, za nevýhodu lze označit sklon $\mathrm{k}$ relativně nízké inkluzi demokratických preferencí. Politické prostředí v tomto systému je z principu vysoce konkurenční - vláda a opozice jsou protichůdné síly, hlasují opačně a jednotně, základní logika politického konfliktu je tedy logika hry s nulovým součtem. Protikladem tohoto modelu je podle Arenda Lijpharta (1984; 1999) model konsensuální demokracie, jenž je naopak založen na logice dostředivého vyjednávání a pojí se především s logikou systémů více než dvou stran. Politická interakce $\mathrm{v}$ tomto modelu je postavena zejména na spolupráci s cílem dosažení kompromisu, viditelný konflikt při hlasování je tudíž menší podstatné rysy návrhů či samotné zahrnutí položek jednání jsou často dojednávány předem (při určování agendy, při př́pravě „legislativního kalendáře“, prostřednictvím dosazování kompromisních kandidátů atd.), politický konflikt má 
tedy odlišnou povahu, je nepřímý a v porovnání s westminsterským relativně více skrytý v komplexitě politických aktérů.

Reálné podmínky současných parlamentních systémů se do jisté míry přibližují uvedeným typům, čisté případy ale nenacházíme. Pokud se zaměříme na klíčové (avšak nejobtížněji konceptualizovatelné) kritérium logiky interakce mezi vládou a opozicí (v Lijphartově teorii kritérium „dominance vlády“) a ostatní kritéria zanedbáme, lze však rríci, že současné parlamentní demokracie zpravidla nedisponují předpoklady pro existenci trvalého, otevřeného konfliktu, protože téměř nevyužívají většinové volební systémy, pojí se se stranickými systémy více než dvou stran a mají tendenci vytvářet koaliční vlády různých typů (včetně nadbytečných nebo menšinových) a pestré formy parlamentní opozice. ${ }^{2}$ Inkluzivita takového nastavení je zpravidla vyšší než v př́padě systému dvou stran, což si někteří odborníci spojují s vyšší stabilitou a celkovou společenskou utilitou proporcionálních, koaličních demokracií (srov. Colomer 2011). Možnost přivést vládu $\mathrm{k}$ politické odpovědnosti je však logicky menši - odpovědnost je zastřená, má nepřímý charakter, je sdílena mezi více aktéry (Novák 2001; Mair 2011: kap. 2) a schopnost skládat účty, a dokonce i plnit volební sliby, klesá (Stokes 1999: 121). Političtí aktéři v tomto prevládajícím institucionálním nastavení jsou relativně méně exponováni; opozice není skutečnou institucí, je méně soudržná a více nestálá (Duverger 1965: 414; Kubát 2010: 56-57, 59, 103). ${ }^{3}$

\section{b. Dynamika politického konfliktu a jednota hlasování}

Podoba interakce mezi vládou a opozicí je tedy fundamentálně propojena s otázkou podoby politického konfliktu - zda je otevřeně konkurenční, nebo naopak neprrímý. Zatímco videálně-typickém westminsterském modelu je konkurence vnitřním rysem institucí a v konsensuálním systému je naopak méně viditelná, v běžných podmínkách skutečných demokracií lze předpokládat, že jde o vlastnost závislou na situaci a na kontextu. S rostoucím počtem stran v parlamentu a ve vládě se situace komplikuje a otevírají se nové kombinační možnosti, protože vládní a opoziční blok je méně koordinovaný a více heterogenní. Vláda a vládou ovládaná legislativní koalice může jednat s různou, obtížně uchopitelnou mírou „,vstřícnosti“ k politickým oponentům, zejména vůči parlamentní opozici - v závislosti na tom, kolik relevantních aktérů v systému existuje, jak důležité je aktuální politické téma a jaké prostředky (moc, informace, strategické volby) mají jednotliví aktéři k dispozici.

\footnotetext{
2 Oboustranné versus jednostranné, rozptýlené versus koncentrované nebo dokonce vnější versus vnitřní, kde vnitřní je opozice uvnitř vládního bloku (Novák 1997: 227).

${ }^{3} \mathrm{~V}$ Evropě často navíc dochází $\mathrm{k}$ oslabování opozice $\mathrm{v}$ důsledku europeizace, která vede jak $\mathrm{k}$ umenšování relevance aktérů nepodílejících se na exekutivě, tak $\mathrm{k}$ poklesu významu parlamentů jako takových (Kubát 2010: 48-50). Současně se ve vybraných státech projevuje tzv. racionalizace, která představuje posílení role vlády vzhledem k parlamentu za účelem zvýšení efektivity a stability vládnutí (ibid.; Kysela 2008: 32-36; srov. Ferejohn 1999: 134).
} 
Jakým způsobem vlastně prakticky uchopit koncept politického konfliktu v prostředí politických institucí? Miroslav Novák (1997: 229-230) v souladu s R. A. Dahlem (1951) definuje vztah konfliktnosti či konkurence mezi politickými stranami $\mathrm{v}$ parlamentu jako situaci, kdy spolu strany (zejména $\mathrm{v}$ klíčových hlasováních) nemohou tvořit vítěznou koalici, tj. tehdy, když se aplikuje logika hry s nulovým součtem, pokud hlasují proti sobě. Soutěživost a konkurenci přitom ovlivňuje podoba stranického systému, zejména koncentrovanost opozice (počet opozičních stran a jejich schopnost hlasovat jednotně). Absolutni konkurence je proto v systémech více než dvou stran nepravděpodobná či dokonce nemožná. Novák (1997: 225-228; 231) také uvádí hledisko koncentrace opozice ve smyslu počtu stran a jednotnosti hlasování mezi hlavními kritérii odlišujícími povahu a formu politické parlamentní opozice. Čím více ve fungování politického systému převládá logika dvou soupeřících bloků spíše než několika různě spolupracujících center moci, tím více je systém konkurenční (resp. tím více je politický konflikt otevřený a viditelný, spíše než nepř́mý a skrytý). V tomto ohledu představují nově demokratizované systémy, jako bývala Česká republika, zajímavý výzkumný materiál.

Duvergerův a Novákův argument ale není nutno vnímat pouze mechanicky stejnou logiku lze uplatnit i při výzkumu behaviorálního rozměru (tj. při zkoumání toho, jak strany jednaji). Zvláštní místo v úvahách o politickém konfliktu proto zaujímá otázka jednoty hlasování - její zkoumání je způsobem, jak konceptualizovat koncentrovanost opozice a tedy i intenzitu konkurence politického konfliktu. Jednota hlasování je přímou funkcí míry konkurence mezi politickými stranami (Golembiewski 1958: 501; Shaun, Farrell a Katz 1999: $13-$ 14). Zároveň platí, že tuto otázku není nutné spojovat výlučně s úrovní politických stran - výzkumnou perspektivu má smysl rozšírít i na úroveň koalic a parlamentních bloků (Carey 2009: 159). Úvaha o propojenosti intenzity politického konfliktu, polarizace a jednoty hlasování je logická: Představme si hlasování, na jehož výsledku mají aktéŕi mimořádný zájem. Pokud má aktér realistickou šanci přehlasovat oponenty, je jednota cestou $\mathrm{k}$ protlačení takové verze legislativního návrhu, který se nejvíce bliží jeho preferencím. Pokud je aktér výrazně slabší a nemůže počítat s výhrou, motivací k jednotnému hlasování je snaha profilovat se na konfliktním tématu - demonstrovat vlastní pozici voličům. Jednota má samožrejmě pro slabší blok v porovnání se silnějším o něco menší význam, ale na druhou stranu i menšina může vyhrát, pokud je většina nejednotná. Investice do nákladů spojených s použitím kompletního hlasovacího potenciálu je tak ve všech př́padech racionální.

Jednání poslance se prrirozeně neřídí jen tím, zda patři do vládního či naopak opozičního bloku. Hlasování v parlamentu se může odehrávat s různou mírou komplexity, hlasovací dimenze vláda versus opozice není jediná relevantní. V multipartismech využívajících proporční volební systém nacházíme standardně více dimenzí než v systémech dvoustranických, klíčová je často i dimenze levice - 
pravice (Hix a Noury 2011). Jak vláda, tak opozice mohou jednat jednotně i nejednotně, tj. mohou využívat svůj maximální hlasovací potenciál či nikoli, účinnost jejich strategie však obvykle roste s jednotou. Tato studie si vybírá jednu konkrétní hlasovací dimenzi, která je pro její téma nejdůležitější, protože dimenze vláda versus opozice má v parlamentních demokraciích jako jediná systémový charakter (vláda je typicky závislá na důvěre většiny parlamentu) a také přímo navazuje na debatu o typech demokracie.

Faktem také je, že jednota hlasování coby empiricky pozorovatelná veličina je výsledkem složitých a skrytých strategií. Má na ni vliv jak míra ideologické koheze (vnitřní motivace, podobnost preferencí jednotlivých zákonodárců), tak stranická disciplína (vnější motivace, př́nucení stranickým vedením; srov. Ozbudun 1970: 305; Borz 2006; Sieberer 2006; Lyons a Lacina 2009 aj.). Poslanci mohou navíc hlasovat upř́mně i strategicky. Tyto motivace jsou však z hlediska fungování systému podružné - důležitější roli hraje fakt, jaká institucionálně-behaviorální ekvilibria (stabilní situace) má daný systém sklon vytvářet, jaký typ interakce mezi vítězi a poraženými zde převládá. Platí také, že protože je (téměř) dokonalá jednota opozice v multipartismu spíše méně častým jevem, o to jednoznačnější je identifikace konfliktních hlasování (která jsou skutečně důležitá).

Obecné faktory mající vliv na jednotu stran a koalic jsou známé. Např. John Carey (2000: 1-2; 2007: 92n.) uvádí, že předpoklad jednotnosti hlasování bývá logicky spojován s parlamentními spíše než prezidentskými systémy, vládními spíše než opozičními stranami a s těsnými spíše než pohodlnými vládními většinami. Z časového hlediska se předpokládá, že jednota bude vyšší na začátku funkčního období spíše než na konci, nebot' výhodnost udržet stávající koalici se časem zmenšuje a naopak narůstá riziko rozštěpení (Diermeier a Feddersen 1998). Dosavadní práce dokládají, že vládní strany jsou přirozeně jednotnější než opoziční a mají zpravidla větší úspěch při hlasování (srov. Prata 2006; Paskalev 2002). Takové závěry jsou sice intuitivní a logické, avšak velmi široké a obecné. Při výzkumu reálných demokracií se není třeba omezovat na uvažování o absolutních, trvalých a vzájemně se vylučujících kategoriích, do kterých by snad mohly být systémy zařazeny jako celky. Žádný parlament nefunguje $\mathrm{v}$ jednom modu trvale (srov. Novák 1997: 229) a požadavky na výzkum dynamiky, časové dimenze a nižších celků dat ostatně pravidelně vyplývají z teoreticko-metodologických diskusí. Požadovaným cílem je odhalit informace, jež jsou při tradiční práci s vysoce agregovanými daty skrytá (srov. Sieberer 2006: 171; Skjæveland 1999: 121). Tato studie proto pracuje s funkčními obdobími vlád nebo dokonce se sériemi hlasování, nikoli se systémem jako celkem. Sledování, jak často a s jakou intenzitou vládní blok přehlasovává opoziční strany, popř́padě jak často se opozice aktivizuje a snaží blokovat kroky vlády, je tedy jednoduchou analýzou proměnlivé míry konfliktnosti v práci parlamentu. 


\section{c. Parametry parlamentního konfliktu v České republice}

Minimálně ve zkoumaném období byla Česká republika označována za konsolidovaný demokratický systém, který se během svého vývoje od počátku devadesátých let 20. století prriblížil praxi západoevropských států, ačkoli jeho fungování na začátku částečně vykazovalo přirozeně chaotické uspořádání, a u něhož se (navzdory jistým specifikům co do fungování stranického systému nebo stability vlád) předpokládala postupná konsolidace a ustalování pravidel hry (Mansfeldová 2005; Lyons a Lacina 2009; Havlík 2011). ${ }^{4}$ Centrální roli v politickém systému ČR má parlament, který v souladu s očekáváním představuje klíčovou arénu pro stř̌et vlády a opozice. Pravomoc vlády vůči parlamentu není prŕliš posílena (Kysela 2003; 2008). Parlament je bikamerální se silně dominantní rolí dolní komory - Poslanecké sněmovny. Zákon odhlasovaný Sněmovou může být navrácen Senátem nebo prezidentem republiky, Sněmovna však může vrácený návrh přehlasovat absolutní většinou. Vliv těchto dvou vetohráčů (blokujících aktérů) je tedy slabý a dále se jimi nebudeme zabývat.

Typ parlamentní interakce závisí do značné míry na typu parlamentní opozice. Politolog Michal Kubát (2010: 92-94, 103-107) v České republice ve zkoumaném období určil opozici zpravidla dobře rozlišitelnou, ${ }^{5}$ na levici slabě fragmentovanou a (vlivem působení KSČM) polarizovanou, na pravici pak slabě fragmentovanou a (po odchodu SPR-RSČ ze systému) nepolarizovanou. Vládněopoziční konflikt není absolutní, soutěž a spolupráce se v systému prolínají a kombinují v závislosti na okolnostech. Analýzy Poslanecké sněmovny nachází pŕítomnost obvykle dvou dimenzí hlasování. Dimenzi levice versus pravice a vláda versus opozice však obvykle nelze přesně oddělit, protože jejich přesné určení často znemožňuje problém observační ekvivalence (Lyons a Lacina 2009: 1159n.).

Fungování Poslanecké sněmovny od prvního do pátého období (1990-2010) ilustruje expert na ústavní právo Jan Wintr (2010: kap. 2), jenž analyzuje dílčí oblast politics - parlamentní kulturu - tak, že popisuje vybrané parlamentní debaty, jež definovaly jednotlivé fáze. Již do druhého období Wintr umist’uje pomyslný přechod stylu jednání od „pracovního parlamentu“ k „parlamentu proslovư — s tím, jak vzrostlo využívání obstrukcí a vyostřily se debaty mezi vládou a opozicí, minimálně při jednání spojeném s hlasováním o rozpočtu. Konfliktnost a celkový styl práce Sněmovny podle Wintra závisely mimo jiného na klíčovém faktoru velikosti vládní většiny a jasnosti hlasovacích poměrů mezi vládou a opozicí; klidnější byly $\mathrm{v}$ tomto ohledu první Klausova a Zemanova vláda, bouřlivější naopak vlády po roce 2002. Podle logiky typologie politické opozice Sylvie Giulj (1981), jež rozlišila tzv. smílivou a konfrontační parlamentní opozici, Wintr

\footnotetext{
${ }^{4}$ Současný vývoj tato hodnocení problematizuje, situace po roce 2013 již však leží mimo záběr tohoto textu.

5 Výjimku z pravidla rozlišitelnosti opozice představuje období „opoziční smlouvy“.
} 
identifikoval celkově smírlivé jednání opozice v prvním období, kombinace ve druhém a třetím, a konečně přechod ke konfrontační opozici ve čtvrtém a pátém období. Konfrontační opozice byly ale poměrně úspěšné z hlediska legislativních návrhů - což ukazuje na slabost vlád ve vztahu ke Sněmovně (Wintr 2010: $297-$ 298; srov. Kubát 2010: 68-69).

Klíčovou otázkou je, zda a jak se případná změna interakce a logiky vládnutí odráží na kvantitativních ukazatelích jednoty hlasování vlády a opozice, které se konceptuálně vztahují ke koncentrovanému postupu obou bloků a v důsledku tedy k polaritě hlasování. Jak přesně se tedy jednotlivé české vlády v období mezi lety 1993 a 2013 lišily v intenzitě vládně-opozičního konfliktu? A pokud došlo ke změně, byla postupná, nebo lze vysledovat jeden či více přelomových bodů?

\section{Metody a měření}

\section{a. Indexy jednoty hlasování}

Analýza využívá dvou jednoduchých indexů jednoty hlasování: Za prvé je to klasický, široce využívaný Riceův index (Rice 1925), za druhé jeho novější modifikace, index UNITY amerického politologa Johna Careyho (Carey 2000; 2007; 2009). Oba ukazatele jsou založeny na měření vzájemného poměru zákonodárců, kteři hlasovali pro odlišné možnosti. Rozdíl mezi oběma nástroji spočívá $\mathrm{v}$ tom, že zatímco původní Riceův index do výpočtu započítává pouze osoby, kteři hlasovali pro návrh nebo proti návrhu, index UNITY bere ohled na velikost celé skupiny (strany či koalice), a zahrnuje tudíž i členy, kteří se z jakýchkoli důvodů formálně zdrželi hlasování nebo se aktu vůbec neúčastnili. Pro jednání skupiny $i$ při hlasování $j$ platí, že:

$$
\begin{array}{cc}
\text { RICE }_{i j}=\mid \% \text { PRO }_{i j}-\% \text { PROTI }_{i j} \mid & (\% \text { hlasujících }), \\
\text { UNITY }_{i j}=\mid \% \text { PRO }_{i j}-\% \text { PROTI }_{i j} \mid & (\% \text { všech }) .
\end{array}
$$

Riceův index nabývá hodnoty $0 \%$ (pokud skupina vykazuje stejný podíl hlasů pro návrh i proti návrhu) až $100 \%$ (pokud skupina hlasuje zcela jednotně, lhostejno pro kterou možnost). Index UNITY nabývá hodnoty 0 \% (pokud nikdo nevolí ani možnost pro návrh, ani proti návrhu, nebo pokud se skupina rozdělí na dva stejné tábory podobně jako v př́edchozím př́padě) až $100 \%$ (kdy se celá skupina účastní hlasování a hlasuje pro kteroukoli stejnou možnost). Pokud např. ve stočlenném bloku hlasuje 50 poslanců PRO NÁVRH, 10 PROTI a 40 vůbec nedorazí, Riceův index pro toto hlasování je $67 \%$, kdežto index UNITY jen 40 $\%$. Výsledky těchto na první pohled obdobných ukazatelů se tedy výrazně liší tehdy, jestliže se významná část strany nebo koalice nevysloví pro ani jednu ze dvou základních možností - pokud se zdrží nebo neúčastní hlasování. Dá se tedy říci, že zatímco Riceův index měří míru nesouhlasu mezi aktivně hlasujícími, resp. míru ochoty hlasovat proti vedení v rámci strany či koalice (ve smyslu jednota 
versus rozpolcenost), index UNITY měrí schopnost využití hlasovacího potenciálu (maximálního počtu hlasů) za účelem zvrácení výsledku hlasování ve svůj prospěch (ve smyslu jednota versus neakceschopnost). Proto nejlépe funguje za předpokladu, že jednota hlasování je tím důležitější, čím pravděpodobnější je situace, že odpadnutí některých členů bude mít klíčový vliv na výsledek hlasování (Carey 2000: 5n.; 2009: kap. 5).

Careyho index UNITY tedy představuje konceptuálně alternativní metodu, jak nazírat na jednotu hlasování, pokud nás více než koheze preferencí v daném bloku zajímá fungování dané skupiny v reálné interakci s politickými oponenty. V ideálních podmínkách je index UNITY schopen dosáhnout podrobnějšího a jemnějšího výsledku, protože bere ohled na více zdrojových informací. Toto nastavení však jednak zvyšuje nároky na jeho interpretaci a jednak jej činí relativně méně spolehlivým v situacích, kdy se ve zkoumaných legislativních tělesech uplatňují různé neformální dohody (strany mohou např. tolerovat omezený nesouhlas svých poslanců, pokud předpokládají, že je to v dané situaci neohrozí, nebo mohou uzavírat dohody o nehlasovánî). Protože postihnout neformální ekvilibria týkající se nehlasování je z podstaty složitější než porovnat prostou míru nesouhlasu, John Carey (2009: 96-101) po pokusu o aplikaci ukazatele na systémy jižní Ameriky zmírnil své počáteční nadšení pro index UNITY coby nástroj pro komparaci různých parlamentů, jelikož strany uplatňující neformální dohody tohoto typu mohou být ve skutečnosti jednotnější, než se zdá z výsledků.

Jak je tomu v př́padě výzkumu jednoho tělesa? Vzhledem $\mathrm{k}$ tomu, že není nutné brát ohled na rozdílnost pravidel mezi prrípady, je riziko zkreslení menší, stále je však nutno počítat s negativním vlivem, který na přesnost indexu UNITY mají neformální mechanismy. V tomto ohledu představuje $v$ českém př́padě nejvýznamnější riziko zkreslení tzv. párování. Jedná se o dlouhodobě uplatňovanou neformální dohodu mezi vládou a opozicí. Spočívá v tom, že se poslanec z vládního bloku plánující nepríitomnost na hlasování dohodne s poslancem z bloku opozičního, aby na hlasování rovněž nedorazil. Protože oběma táborům se symetricky sníží hlasovací potenciál, poměr sil mezi vládou a opozicí zůstává zachován. ${ }^{6}$ Striktně vzato je praxe párování systematicky nepostihnutelná. Při využívání hlasovacího potenciálu koalice a opozice je párování relevantní zejména $\mathrm{v}$ prípadech, kdy jsou oba bloky jednotné a hlasují opačně. I když neznáme přesný počet vypárovaných poslanců, při srovnatelné velikosti bloků je vliv párování symetrický - index UNITY (nikoli Riceův index)

\footnotetext{
${ }^{6}$ Párování je projevem neformální adaptace stran na tradičně těsné vládní většiny, které zvyšuje předvídatelnost práce Sněmovny. Lze na něj nahlížet různými zpơsoby: Na jedné straně praxe nese stopy legislativního kartelu, protože uměle zasahuje do skutečného hlasovacího potenciálu poslaneckých klubů, jenž je prrímým výsledkem vůle voličů. Mezi zastánce opačného - pozitivního - náhledu patří např́klad zmíněný Jan Wintr (2010), jenž párování naopak chápe jako jistou „gentlemanskou dohodu“, která umožňuje alespoň nějaké standardní fungování Sněmovny, a proto ji označuje za projev relativní vyspělosti politické kultury.
} 
se $\mathrm{v}$ daném prípadě potenciálně sníží, resp. rozšíríi se interval jeho spolehlivosti. V ostatních prrípadech, tj. pokud hlasuje relativně menší část bloků a pokud je jednota hlasování malá, lze předpokládat, že párování nebylo uplatněno nebo že je jeho vliv na výsledky zanedbatelný. Tato studie nabízí výsledky dosažené oběma způsoby - jak s využitím Riceova indexu, který je vůči vlivu párování imunní, tak indexu UNITY, který zprostředkovává odlišnou informaci, avšak jeho přesnost klesá s rostoucím počtem vypárovaných poslanců.

Další specifikum, které je nutno při aplikaci indexů jednoty hlasování na př́pad českého Parlamentu zohlednit, je specifická role vota zdržení se hlasování. To totiž není relevantní jen pro stanovení platnosti hlasování, jak je obvyklé v jiných systémech, ale i pro samotný výsledek: Protože návrh potřebuje získat potřebnou většinu kladných hlasů, funguje hlas „ZDRŽEL SE“ v důsledku stejně jako hlas „PROTI NÁVRHU“. Původní verze zde používaných indexů s touto možností nepočítají - formální abstence jsou ignorovány (Riceův index), resp. jsou součástí zbytkové kategorie (Index UNITY). V českém případě má větší smysl počítat s upravenou verzí obou indexů, kde je kategorie \% PROTI součtem podílů hlasů „PROTI NÁVRHU“ a „ZDRŽEL SE“, takže tam, kde není výslovně uvedeno jinak, text pod pojmy Riceův index a Index UNITY dále rozumí jejich české, modifikované varianty (v grafech a tabulkách jsou v zájmu jednoznačnosti uváděny jako Rice2, UNITY2).

Úspěch měření koaliční a opoziční jednoty je podmíněn tím, že parlamentní komoru lze v každém okamžiku rozdělit obvykle na dva bloky (vládní koalici a opozici), resp. na tyto dva bloky a nezařazené poslance. Česká republika tuto podmínku splňuje, protože poslance lze podle jejich prríslušnosti k poslaneckým klubům poměrně spolehlivě rozdělit na vládní, opoziční a nezařazené. ${ }^{7}$ Všechny oficiální přestupy poslanců mezi kluby a rozdělení stran $\mathrm{v}$ průběhu období byly $\mathrm{v}$ datovém souboru zohledněny s presností na dny. Určujícím kritériem byla př́slušnost poslance $\mathrm{k}$ poslaneckému klubu dané strany a stranické složení vlády. Za rozhodující zdroj těchto termínů sloužil informační systém Poslanecké sněmovny (PSP ČR 2014).

Smysluplná analýza jednoty hlasování $\mathrm{v}$ neposlední řadě vyžaduje, aby v daném systému existovala praxe veřejného, zaznamenávaného hlasování. Záznam hlasů by měl být výchozí možností - nemělo by tedy platit, že se výsledky hlasování sledují a zveřejňují až poté, požádá-li o to určitá skupina zákonodárců. V takovém př́padě získaná data odráží spíše strategické motivy aktérů snažících se demonstrovat jednotu nebo poukázat na nejednotu odpůrců (srov. např́. Bütikofer a Hug 2008). I tato podmínka je v Ćeské republice splněna, nebot'

\footnotetext{
7 Skutečnost zahrnuje nuance - poslanec může např́iklad podporovat vládu, aniž by formálně vstoupil do vládní strany. Zjednodušené pojetí je vzhledem $\mathrm{k}$ cílům práce $\mathrm{v}$ pořádku, nebot' fungování neformální podpưrné koalice se na výsledcích projevuje jako hlasování se sníženou intenzitou konfliktu - což přesně je.
} 
Poslanecká sněmovna zveřejňuje detaily prakticky všech hlasování - ručních a utajených je skutečné minimum. Dále je velmi užitečné, pokud hlasování probíhá elektronickou formou a pokud jsou výsledky dostupné v takovém formátu, který prímo umožňuje elektronické zpracování. V tomto ohledu je Parlament ČR nadstandardně otevřeným legislativním tělesem - ačkoli v základu nenabízí podrobnější třídění hlasů podle zadaných kritérií (a není tedy možné např́ílad přímo odlišit procedurální a technická hlasování od finálních), jím zveřejněná data od zavedení systému v roce 1993 (PSP ČR 2014) jsou pro účely analýzy dostatečná a obsahují i množství cenných detailů, se kterými bude možno dále pracovat $\mathrm{v}$ budoucnu.

\section{b. Časová dimenze hlasování: Vektory polarity}

Dosud uvedený popis výpočtu indexů jednoty se týkal jednotlivých hlasování. $S$ dosaženými výsledky lze ale přirozeně dále pracovat - nejčastěji počítat jejich průměrné hodnoty. Tato studie uplatňuje vlastní výzkumný postup: umist'uje jednotlivá hlasování koaličního i opozičního bloku na časovou osu a vytváŕí tak vizualizaci průběhu jednotlivých období. Tímto způsobem můžeme zjistit, jak oba bloky obvykle využívaly svưj potenciál, jaká hlasování byla nejkonfliktnější, zda se období konfliktu periodicky opakovala, např. s tradičně vypjatým hlasováním o rozpočtu, apod. Tato výzkumná logika je inspirovaná analýzou časových řad, jež je však ve své konvenční podobě v tomto př́padě nepoužitelná, protože data nesplňují podmínku pravidelnosti (hlasování probíhají jen $\mathrm{v}$ předem daných dnech, jejich rozdělení v rámci legislativního období je nepravidelné, a jednotkou analýzy je hlasování, nikoli nap̌r. průměr hlasování za měsíc - nebot’ jedině tak lze identifikovat hlasování, které vybočují z běžného průměru).

Pokud index jednoty, tj. informaci o konfliktnosti hlasování, doplníme o dichotomickou informaci o tom, zda daný blok při hlasování uspěl, dospějeme $\mathrm{k}$ jednoduchému způsobu, jak zobrazit průběh interakce koalice a opozice v čase. Do analýzy tak vstupuje prvek vítězství a porážky a ze skalární veličiny se stává vektor: Pokud většina bloku vyjádří preferenci v souladu s výsledkem hlasování, tj. pro $\mathrm{v}$ prípadě přijatého návrhu, nebo proti $\mathrm{v}$ případě zamítnutého, vektor polarity o velikosti indexu jednoty směřuje nahoru $(\uparrow)$. V opačném prípadě logicky směřuje dolů $(\downarrow){ }^{8}$ Stále také platí, že pokud má index nulovou hodnotu (blok byl rozštěpený, resp. nehlasoval), je nulový i vektor. Výsledná časová řada vektorů zobrazuje, s jakým nasazením oba bloky přistupovaly k jednotlivým hlasováním a zda byly výsledky v souladu s jejich preferencemi. Lze tak jednoduše odlišit běžná a konfliktní období. Platí, že velké či časté nasazení opačným směrem značí

\footnotetext{
${ }^{8}$ Formální zápis: Pokud při hlasování j platí, že: [ (výsledek hlasování j = PŘIJATO) a zároveň $(\mathrm{PROj}>\mathrm{PROTIj})$ ] nebo [ (výsledek hlasování j = ZAMÍTNUTO) a zároveň $(\mathrm{PROj}<\mathrm{PROTIj})$ ], vektor pro hlasování i,j je prostý index $(\uparrow)$, jinak výsledek pro hlasování je negativní hodnota indexu $(\downarrow)$.
} 
větší polarizaci vlády a opozice, tj. větší konflikt. Menší vektory naopak značí běžná či nedůležitá hlasování, u nichž za daných podmínek nemělo smysl investovat do zajištění jednoty. Konečně nasazení obou bloků pozitivním směrem ukazuje na konsensuální, aklamační hlasování, případně formální hlasování, které nebylo vnímáno jako politický konflikt. Viz schémata 1-4:

Schéma č. 1. Princip vektorů polarity

\begin{tabular}{|llllllllll|}
\hline Hlasování & 1 & & 2 & & 3 & & 4 & & \\
\hline Výsledek & Přijato & \multicolumn{2}{l}{ Zamítnuto } & Přijato & & \multicolumn{2}{ll}{ Zamítnuto } & \\
\hline Vláda & PRO & $\uparrow$ & PROTI & $\uparrow$ & PRO & $\uparrow$ & PRO & $\downarrow$ & \\
\hline Opozice & PRO & $\uparrow$ & PROTI & $\uparrow$ & PROTI & $\downarrow$ & PROTI & $\uparrow$ & \\
\hline
\end{tabular}

Čím větší je převaha sloupců v jednom směru, tím častější vítězství či naopak porážka daného bloku. Čím vyšší jsou sloupce, tím více kluby projevily snahu o návrhu hlasovat $\mathrm{a} /$ nebo byly vedením motivovány $\mathrm{k}$ tomu, aby využily maximum svého potenciálu. ${ }^{9}$

Za běžných podmínek (zejména pokud vláda disponuje funkční většinou) je úsilí vlády víceméně konstantní: Vláda souhlasí s většinou výsledků, protože je zdrojem většiny návrhů, které Sněmovnou prochází, a má zájem na jejich úspěchu. Místy je však nucena vymezit se proti snahám o pozměnění, pokusům nastolit agendu ze strany opozice nebo legislativním návrhům soupeřů. Typická výše hodnoty indexů závisí na tom, jak jistá si vláda je svou početní převahou. Opozice zpravidla není tak koordinovaná jako vláda, její zájmy jsou relativně heterogenní a její motivace slabší (její přežití nezávisí na schopnosti protlačovat agendu Sněmovnou). Za běžného legislativního provozu průběh hlasování kolísá blízko nuly (resp. na hladině průměrného indexu), protože strany jsou méně jednotné a jejich souhlasná a nesouhlasná stanoviska se z části vyruší. Výjimkou jsou viditelné výkyvy, jež značí nárůst konfliktu (mobilizovanou, cílenou aktivitu během série hlasovánî). Právě tyto výkyvy je možno přiřadit k jednotlivým hlasováním a zjistit tak, jaké téma či jaký typ hlasování vzepětí vyvolal. ${ }^{10}$

Za účelem lepší vizualizace průběhu období lze př́padně vektory vážit. Po zvážení hodnot grafy zachycují stejnou situaci, ale zmenší se vliv hlasování, která

\footnotetext{
9 Grafy skládající se z vektorů polarity jsou vlastně jednodušší alternativou pro analýzy, které sledují úspěšnost legislativních návrhů stran a koalic. Tato informace v České republice není př́mo dostupná. Analýza se zakládá na velmi zjednodušeném předpokladu, že bloky hlasují pro ty návrhy, které předložily a/nebo se kterými souhlasí.

10 Alternativou zkoumání dané dimenze hlasování (vláda versus opozice) je klasické prostorové modelování hlasování. Jeho smyslem je identifikovat podobně hlasující jedince a následně ex post určit dimenze, které skupiny rozdělují (např. vláda versus opozice, levice versus pravice, EU versus národní stát). Př́istup této studie je opačný: Dimenze, která nás primárně zajímá, je známa předem, vyplývá z debaty o demokratických typech a modelech vládnutí.
} 
prošla tak pohodlně, že byla patrně méně konfliktní, u obou bloků tedy lépe vyniknou polarizující hlasování. Konfliktnější hlasování se do výsledků tedy promítají výrazněji než aklamační. K vážení vektorů $v$ této studii byl použit Careyho index CLOSE, který zvyšuje hodnotu těch hlasování, která prošla těsně, a naopak snižuje vliv těch, na kterých byla v komoře velká shoda. Vážený index UNITY označuji v grafech v souladu s konvencí jako WUNITY. ${ }^{11}$

\section{Výsledky srovnání}

\section{a. Přehled kabinetů a jejich vzájemná pozice}

Mezi lety 1993 a 2013 v Česku vládlo devět vlád (na kabinety V. Špidly, S. Grosse a J. Paroubka se v tomto kontextu pohliží jako na jednu vládu, vzhledem k tomu, že se nezměnil klíčový ukazatel - stranické složení koalice a opozice). U všech vlád včetně polopolitických či úřednických lze relativně snadno odlišit vládní a opoziční strany podle kritéria účasti ve vládě (úřednické kabinety však přirozeně zůstávají specifickou kategorii). Výjimku představuje pouze kabinet Miloše Zemana, který je vzhledem k nejednoznačné roli ODS vhodné za cenu jistého zjednodušení rozdělit na dva prrípady ( $v$ prvním př́padě se za vládní stranu považuje pouze ČSSD, ve druhém ČSSD i ODS). ${ }^{12}$ Opět platí, že poslance tvořící tzv. podpůrné koalice $\mathrm{v}$ tomto typu analýzy lze bez většího rizika zanedbat; jejich působení se projevuje výsledné podobě indexů (viz pozn. 7). Rozdíly v koncentrovanosti jednotlivých vlád a opozičních bloků jsou dobře patrné a shrnuje je tabulka 1. Povšimněme si posílení opozice ve druhé polovině zkoumaného období, at' už jde o její dominanci v překlenovacích kabinetech (Topolánek I a Fischer) nebo vyrovnanou aktivizaci vlády a opozice v politických kabinetech (Topolánek II a Nečas):

11 Výpočet: CLOSEj $=1$ - (1 / Kvórum •| Kvórum - \%Pro |), resp. 1 - (2 • | $50 \%$ - \%Pro |) za předpokladu, že je kvórum vždy relativní a ke schválení stačí nadpoloviční část př́tomných (Carey 2007: 97; 2009: 113-116).

12 Byt' je tento prŕpad spíše hypotetický, viz diskusi v Kubát 2010: 105-107. 
Tabulka č. 1: Vlády České republiky, 1992-2013

\begin{tabular}{|c|c|c|c|c|c|c|c|}
\hline \multirow[t]{3}{*}{$\begin{array}{l}\text { Vláda (trvání, složení, typ } \\
\text { koalice) }\end{array}$} & \multirow[t]{3}{*}{$\begin{array}{l}\text { Stáří } \\
\text { (dnů) }\end{array}$} & \multirow{3}{*}{$\begin{array}{l}\text { Důvěra } \\
\text { (na } \\
\text { začátku) }\end{array}$} & \multirow{3}{*}{$\begin{array}{l}\text { Počet } \\
\text { hlaso- } \\
\text { vání }\end{array}$} & \multicolumn{4}{|c|}{$\begin{array}{l}\text { Průměrné prosté hodnoty } \\
\text { ukazatelů }\end{array}$} \\
\hline & & & & \multicolumn{2}{|l|}{ Rice2 } & \multicolumn{2}{|c|}{ UNITY2 } \\
\hline & & & & Vláda & Opozice & Vláda & Opozice \\
\hline $\begin{array}{l}\text { V. Klaus I: 1992-1996 } \\
\text { (ODS+KDS+KDU-ČSL+ODA, } \\
\text { minimálně vítězná ideově } \\
\text { propojená) }\end{array}$ & 1420 & $\begin{array}{l}\text { 106/200 } \\
\text { (koalice: } \\
105 \text { ) }\end{array}$ & $\begin{array}{l}5166 \\
13\end{array}$ & 0,78 & 0,59 & 0,58 & 0,37 \\
\hline $\begin{array}{l}\text { V. Klaus II: 1996-1998 } \\
\text { (ODS+KDU-ČSL+ODA, } \\
\text { menšinová) }\end{array}$ & 559 & $\begin{array}{l}\text { 98/138 } \\
\text { (koalice: } \\
99 \text { ) }\end{array}$ & 3427 & 0,86 & 0,61 & 0,76 & 0,55 \\
\hline $\begin{array}{l}\text { J. Tošovský: } 1998 \\
\text { (Fakticky KDU- } \\
\text { ČSL+ODA+US, úřednická) }\end{array}$ & 747 & $123 / 197$ & 1514 & 0,77 & 0,45 & 0,60 & 0,36 \\
\hline \multirow{4}{*}{$\begin{array}{l}\text { M. Zeman: 1998-2002 } \\
\text { (ČSSD / ČSSD+ODS, } \\
\text { menšinová) }\end{array}$} & \multirow[t]{4}{*}{1454} & \multirow[t]{4}{*}{ 73/136 } & \multirow{4}{*}{$\begin{array}{l}14 \\
000\end{array}$} & \multicolumn{4}{|c|}{ Pokud vláda = ČSSD } \\
\hline & & & & 0,83 & 0,67 & 0,71 & 0,56 \\
\hline & & & & \multicolumn{4}{|c|}{ Pokud vláda = ČSSD + ODS } \\
\hline & & & & 0,82 & 0,55 & 0,70 & 0,44 \\
\hline $\begin{array}{l}\text { V. Špidla/S. Gross/J. } \\
\text { Paroubek: } 2002-2006 \\
\text { (ČSSD+KDU-ČSL+US-DEU, } \\
\text { minimálně vítězná ideově } \\
\text { nepropojená) }\end{array}$ & 1438 & $\begin{array}{l}\text { 101/199 } \\
\text { (koalice: } \\
101 \text { ) }\end{array}$ & $\begin{array}{l}14 \\
112\end{array}$ & 0,79 & 0,52 & 0,65 & 0,43 \\
\hline $\begin{array}{l}\text { M. Topolánek I: 2006-2007 } \\
\text { (ODS, menšinová) }\end{array}$ & 193 & $96 / 195$ & 867 & 0,70 & 0,65 & 0,59 & 0,56 \\
\hline $\begin{array}{l}\text { M. Topolánek II: 2007-2009 } \\
\text { (ODS+KDU-ČSL+SZ, } \\
\text { menšinová) }\end{array}$ & 1068 & $\begin{array}{l}\text { 100/198 } \\
\text { (koalice: } \\
100)\end{array}$ & 4883 & 0,81 & 0,75 & 0,67 & 0,63 \\
\hline $\begin{array}{l}\text { J. Fischer: 2009-2010 } \\
\text { (Fakticky ODS+ČSSD+SZ, } \\
\text { úřednická) }\end{array}$ & 380 & $156 / 194$ & 2513 & 0,49 & 0,68 & 0,35 & 0,55 \\
\hline $\begin{array}{l}\text { P. Nečas: 2010-2013 } \\
\text { (ODS+TOP09+VV/LIDEM, } \\
\text { minimálně vítězná ideově } \\
\text { propojená) }\end{array}$ & 1123 & $\begin{array}{l}\text { 118/200 } \\
\text { (koalice: } \\
118 \text { ) }\end{array}$ & 5604 & 0,84 & 0,69 & 0,66 & 0,54 \\
\hline
\end{tabular}

Zdroj informací o typu koalic: Havlík (2011: 74)

${ }^{13}$ Pouze za dobu od 543. dne do konce období (nedostupnost dat před nasazením elektronického systému). 
Při analýze jednoty hlasování v České republice lze rozpoznat rozdíly mezi oběma indexy, tj. mezi oběma rozměry jednoty hlasování: Pokud se soustředíme na jednotu ve smyslu vnitřní koheze ve straně či koalici (tj. na klasické podíly hlasů pro a proti návrhu, které měří Riceův index), je jednota zejména ve vládním bloku značná a $\mathrm{v}$ některých př́padech podstatě trvalá, jak ostatně zjistily už předchozí studie (srov. např. Gregor a Havlík 2013: 560). Pokud se naopak ptáme na jednotu ve smyslu využívání hlasovacího potenciálu v souladu s logikou indexu UNITY (hlasování všech členů strany či koalice), jednota je obvykle výrazně nižší a vykazuje také mnohem větší varianci. Díky tomu, že jednota ve smyslu indexu UNITY je více proměnlivá, je (navzdory potenciálně snížené spolehlivosti způsobené párováním) možné odlišit exponovaná hlasování, což v českém prostředí Riceova metoda ne vždy dovoluje (indexy jsou v některých př́padech např. během vlády Petra Nečase - stabilně vysoké, především u vládních stran): Semknutí bloků a vysoký index UNITY ukazuje na to, že dané hlasování bylo vnímáno jako relativně důležitější a mělo smysl hlasovat konfliktně (tj. investovat náklady do koaliční jednoty). V tomto odlišení, resp. doplnění informací tedy spočívá nejvyšší hodnota novějšího ukazatele.

Variance a rozdíly mezi jednotlivými časovými úseky jsou relativně větší v prrípadě „českých“ variant ukazatelů než v případě původních verzí - zdržení se a nehlasování významně kolísá mezi hlasováními a má klíčový vliv na výsledky. České verze ukazatelů (Rice $\times$ UNITY2) pro jednotlivé bloky a hlasování spolu také vysoce korelují (zatímco originální varianty o poznání méně):

\section{Tabulka č. 2: Pearsonův korelační koeficient pro dvojice variant ukazatelů.}

\begin{tabular}{|l|l|l|l|l|}
\hline RICE & $*$ & & & \\
\hline RICE2 & 0,63 & $*$ & & \\
\hline UNITY & $\mathbf{0 , 7 8}$ & 0,67 & $*$ & \\
\hline UNITY2 & 0,57 & $\mathbf{0 , 9 2}$ & 0,77 & $*$ \\
\hline & RICE & RICE2 & UNITY & UNITY2 \\
\hline
\end{tabular}

Následující grafy zobrazují vzájemné srovnání českých vlád nejen podle kritéria prosté jednoty (uvedeného $\mathrm{v}$ předchozí tabulce), ale také podle kritéria vítězství a porážky. Porovnávají proto nevážené průměrné hodnoty vektorů polarity pro vládu a opozici. Teoretické krajní možnosti spektra jsou následující:

- Levý horní pól: čistá dominance vlády (vláda je jednotná, opozice pasivní či rozdělená),

- pravý spodní pól: čistá dominance opozice (opačný př́pad),

- levý spodní kvadrant: jednostranné hlasování (oba bloky často konsensuálně vyjadřují podporu návrhům - typické pro převahu 
technických hlasování nebo hlasování, která nejsou vnímána jako politická).

Graf č. 1: Srovnání vlád podle vektoru UNITY (,česká“" varianta).

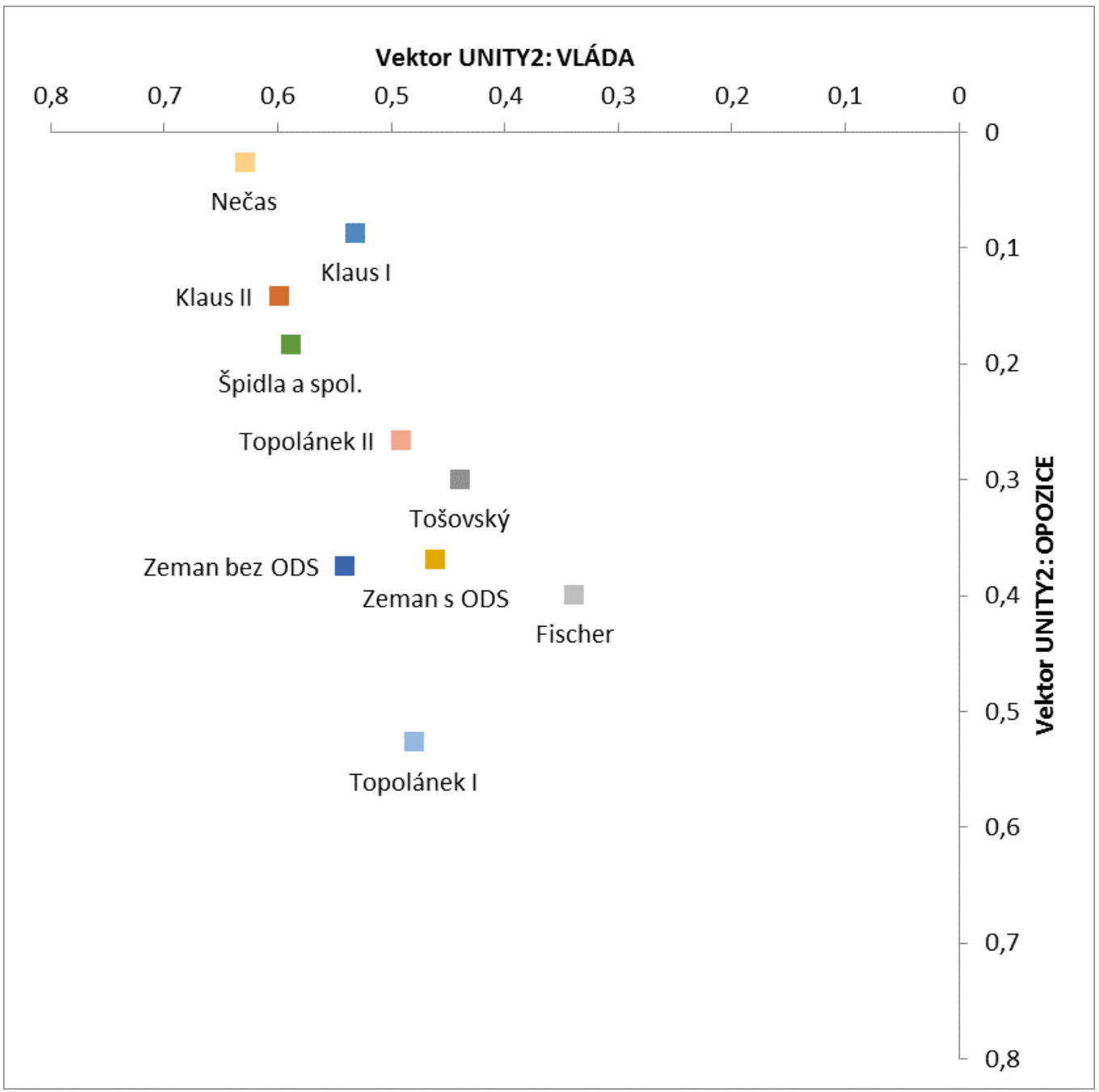


Graf č. 2: Srovnání vlád podle vektoru RICE2 (,česká"“varianta).

\section{Vektor RICE2: VLÁDA}

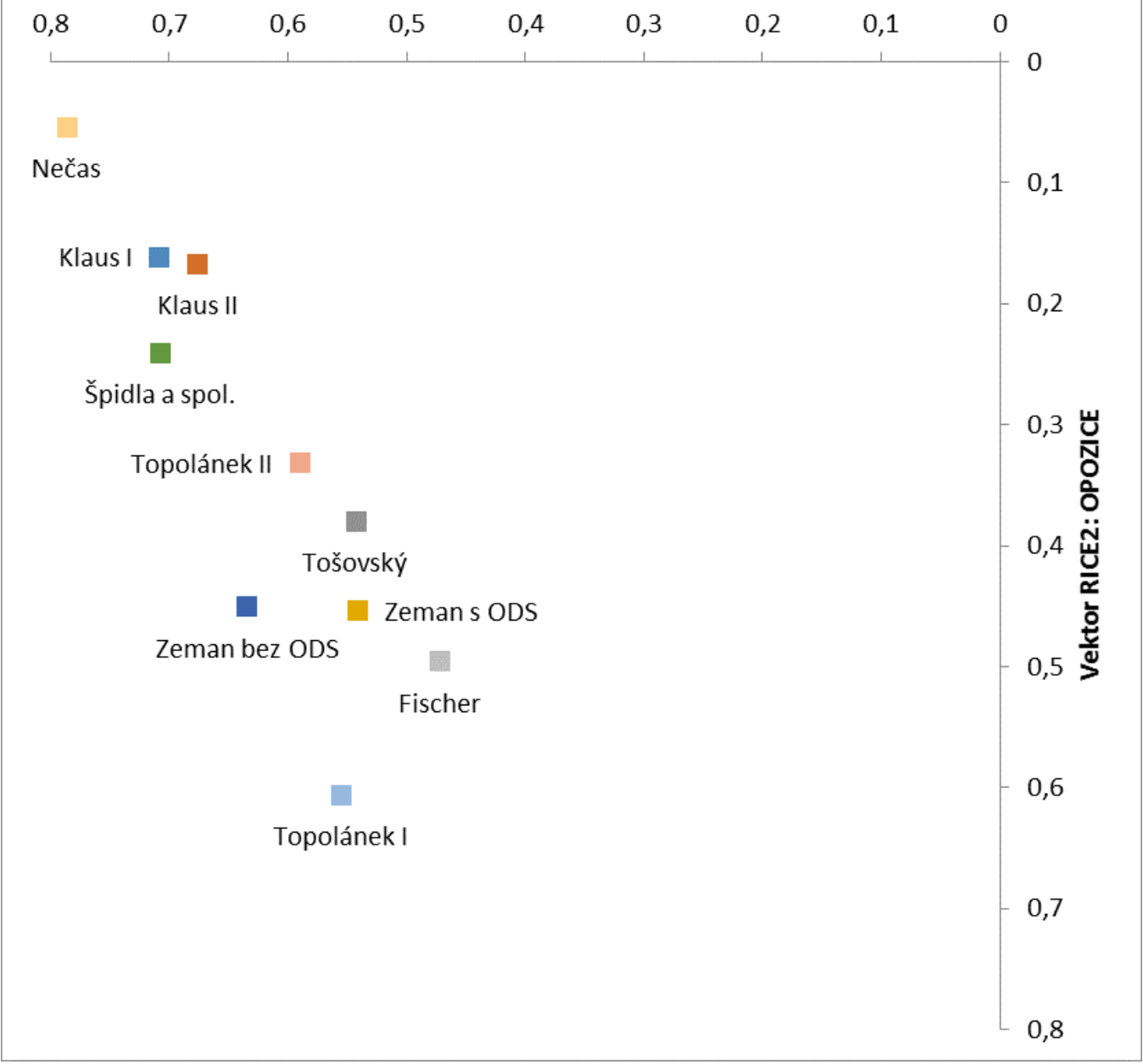

Co se týče vzájemných relativních pozic vlád, obě varianty zkoumaných vektorů indexů (standardní i „česká") vykazují obdobné výsledky. Ačkoli se přirozeně mění hodnoty jednotlivých variant ukazatelů (viz tabulka 1), korelace indexů je vysoká a vzájemná pozice jednotlivých vlád zůstává obdobná. ${ }^{14}$ Párování tedy ze zkoumaného hlediska nepředstavuje výrazný handicap co do prresnosti

\footnotetext{
${ }^{14}$ Jedinou výraznou výjimku představuje umístění kabinetů Klaus I a Nečas: V obou př́padech má opozice logicky velmi malý pozitivní vliv (průměrný vektor se blíží nule). Nicméně platí, že při aplikaci „české“ varianty indexu UNITY (UNITY2) opozice během vlády kabinetu Klaus I vychází jako pozitivněji působící než v období vlády Petra Nečase, zatímco při aplikaci klasické verze indexu je tomu presně naopak.
} 
srovnání jednotlivých př́padů, resp. jeho vliv je mnohem menší než třeba vliv počtu konfliktních hlasování $\mathrm{v}$ porovnání s aklamativními.

Vlády se seřadily na prímku podle míry konkurence, resp. spolupráce s opozicí. Mezi spíše konkurenční paří kabinety Nečas, Klaus I, i II, Špidla a spol., Topolánek II), mezi konsensuální na druhou stranu kabinety Zeman, Tošovský, Topolánek I a Fischer. Tento závěr je intuitivní - období politických vlád disponujících většinou se logicky vyznačují větší konkurencí hlasování než vlády menšinové, polopolitické či jinak nestandardní. Snad důležitější je závěr, že v grafu není patrný jednoduchý, univerzální časový trend - ačkoli opozice výrazně posílila co do jednoty hlasování ve druhé polovině zkoumaného období (viz tabulka 1), relativní pozice kabinetů po započtení kritéria souhlasu a nesouhlasu neodpovídá časové posloupnosti kabinetů (tj. Kabinet Topolánek II podle tohoto hlediska není nejkonfliktnější, ani druhý nejkonfliktnější kabinet, jak by se mohlo zdát z dosavadních kvalitativních popisů o postupné aktivizaci Poslanecké sněmovny nachází se naopak ze standardních vlád nejblíže konsensuální oblasti).

Jako zajímavé se jeví čtyři př́ípady: Za prvé, výrazně se profilující vláda Petra Nečase, která se svým dominantním působením vymyká obvyklým českým institucionálně-behaviorálním vzorcům. Za druhé, je to druhá vláda Václava Klause, jež si v první polovině devadesátých let přes svůj menšinový status a závislost na existenci vládně-opozičního ekvilibria ve Sněmovně zachovala velmi silnou tendenci ke konkurenčnímu jednání. Třetím př́padem je viditelný rozdíl mezi jednotlivými polopolitickými vládami - zatímco první Topolánkova a Fischerova vláda dávala výrazný prostor opozici, dominance Tošovského kabinetu byla o poznání větší a tato vláda se tak posunula mnohem blíže standardním politickým kabinetům (srov. Hloušek a Kopeček 2012). Konečně je to pozice kabinetu Miloše Zemana, který je $\mathrm{v}$ grafu reprezentován dvěma body (jednak ve verzi, kde ČSSD představuje menšinovou vládu, jednak ve verzi, kde je na ČSSD a ODS nahlíženo jako na faktickou koalici) a který se posouvá blíž k aklamativní, nepolitické logice, pokud je na něj nahlíženo jako na menšinovou vládu výhradně ČSSD.

\section{b. Vektory polarity: Časový průběh jednotlivých období}

Po srovnání vzájemné pozice kabinetů jako celků můžeme přistoupit k analýze na nižší úrovni a porovnávat průběhy vládně-opoziční interakce $\mathrm{v}$ jednotlivých obdobích (jednotkou analýzy je $\mathrm{v}$ tomto prŕpadě série hlasovánî). Tato analýza může určit, jak se dominance vlád vyvijela v čase a především jaká byla situace při konkrétních hlasováních a hlasovacích dnech - které př́pady se staly zdrojem konfliktu a v důsledku ovlivnily pozici jednotlivých kabinetů. Na tuto otázku odpoví komparace vizualizovaných vektorů polarity pro vládu v porovnání s opozicí. 
Mezi všemi čtyřmi variantami indexů (Rice, Rice2, UNITY, UNITY2) existuje určitá shoda, obdobný je i průběh časových řad jednotlivých hlasování (s ohledem na jejich logiku a konstrukci) - logicky např́ílad platí, že hodnoty Riceova indexu jsou přirozeně homogennější a vyšší než je tomu u indexu UNITY, index UNITY díky tomu dokáže jemněji modelovat využití potenciálu vlády i tehdy, pokud vykazuje téměř trvale stoprocentní Riceův index). V zásadě platí, že každé období se vyznačovalo vlastní rovnovážnou situací, tj. určitým typem interakce mezi vládou a opozicí, jenž kromě krátkodobých výkyvů převládal po celou dobu působení dané vládní koalice. Pokud se v grafech nachází patrný trend, je vždy jen lokálního, časově omezeného charakteru a obecně ukazuje na nestandardní situaci (př́kladem je oslabení jednoty koaličního bloku v závěrečné fázi vlády druhého kabinetu Mirka Topolánka a současná aktivizace opozice po vyslovení nedůvěry v roce 2009).

Při srovnání průběhu jednotlivých vládních období se jako vhodné jeví odlišit základní typy kabinetů. Polopolitické a překlenovací vlády, které spolu v předchozí kapitole tvořily shluk nestandardních vlád, se logicky těšily zásadní dlouhodobé spolupráci nebo dokonce dominanci opozice, resp. opozice se pozitivně podílela na velké části schválených zákonů a při hlasování tak dimenze vláda versus opozice nehrála určující roli, což vyplývá přímo z charakteru těchto vlád. Tato logika platila pro kabinet Josefa Tošovského (1998), i pro první kabinet Mirka Topolánka (2006-2007), a vůbec nejvýrazněji se projevila v období vlády Jana Fischera (2009-2010), které zachycuje schéma $2:^{15}$

Schéma č. 2: Vláda Jana Fischera, konsensuální udržovací kabinet se silným pozitivním vlivem opozice, resp. nejasným vymezením opozice.

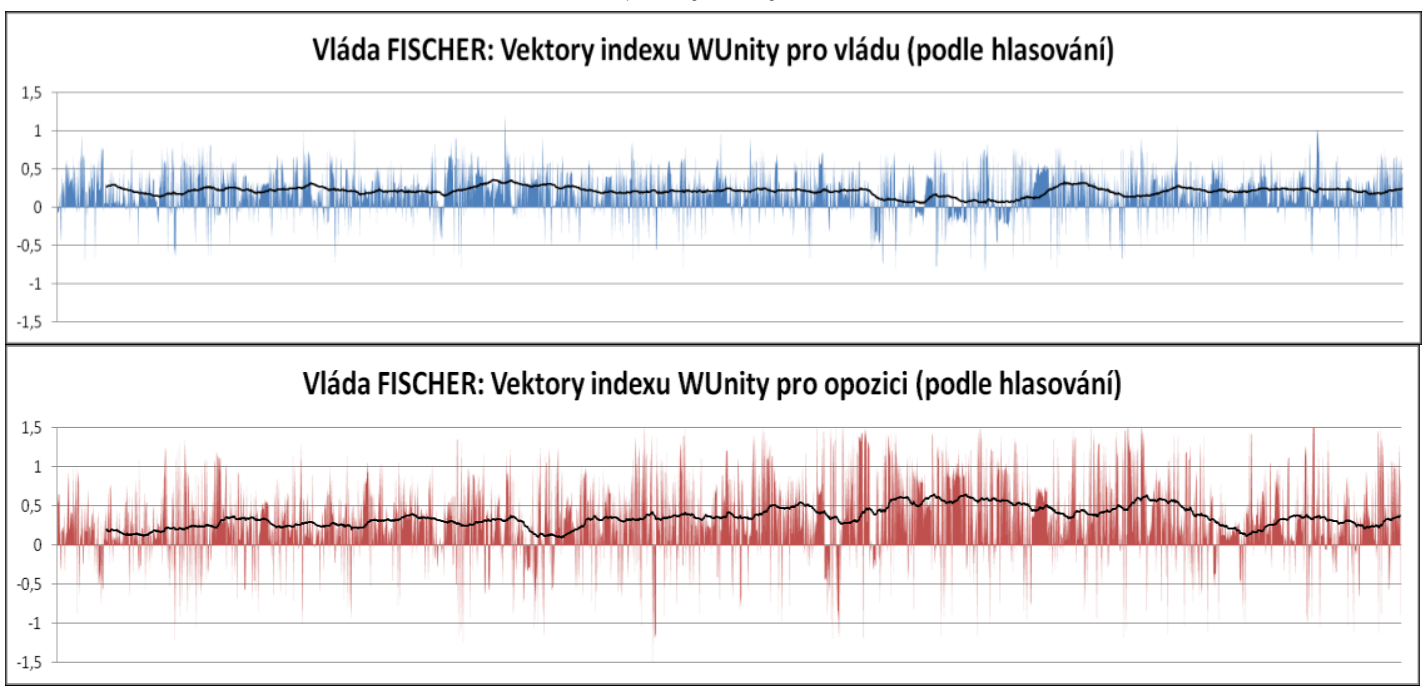

${ }^{15}$ Ve schématech 2-4 jsou vektory Unity pro větší názornost zváženy indexem CLOSE. 
V souboru standardních, politických vlád je situace zajímavější. Zde je vhodné rozlišovat mezi celkovou logikou interakce (ta závisí hlavně na tom, jak velká část opozice dlouhodobě vyslovuje souhlas nebo naopak nesouhlas v hlasováních) a př́pady krátkodobých, nárazových aktivizací (které z dlouhodobé logiky naopak vybočujî). Nejtypičtější situací je model ad-hoc konfliktu, který se vyznačuje tím, že ani vládní, ani opoziční blok není aktivizovaný trvale, nehlasuje dlouhodobě jednotně. Vládní blok je přirozeně jednotnější než nekoordinovaný blok opoziční, ale v zásadě oba bloky zajišt'ují jednotu selektivně (návrh od návrhu v závislosti na jejich důležitosti) a z hlediska času rozptýleně.

Nejčistší př́ípad ad-hoc rozhodování je vláda Miloše Zemana (1998-2002). Specifická konstelace „opoziční smlouvy“ a extenzivní přijímání zákonů Evropských společenství s cílem dokončit harmonizaci českého a evropského práva způsobila, že jak ČSSD, tak ODS i zbytek stran se řídily charakterem daného návrhu, v zásadě všechny tři bloky se pozitivně podilely na legislativě. Podobný průběh vykazuje první vláda Václava Klause (1992-1996). Obdobným, ale mírně odlišným př́padem v této kategorii je také druhá vláda Václava Klause (1996-1998), která se vyznačuje poněkud výraznější polarizací (jednotné, lokálně neohraničené hlasování vlády i opozice v celém průběhu obdobî). Období první vlády Václava Klause bylo z tohoto hlediska naopak „nejklidnějšíi“, což lze přičíst dobovému kontextu (postupné krystalizaci politického a stranického systému a dominantní roli ODS).

Vedle modelu ad hoc rozhodování lze identifikovat ještě model dlouhodobé polarizace, do nějž by patřil kabinet Petra Nečase. Zde byla obvyklá koncentrace tak vysoká, že se vektory pro opozici i v „klidných obdobích“ typicky pohybovaly v negativních hodnotách, což ukazuje na trvalý nesouhlas s vládou. Během tohoto období lze sice pozorovat prvky ad-hoc strategie, nicméně Nečasova vláda porážela relativně vysoce aktivizovanou opozici v podstatě pravidelně - opozice se pozitivně podílela jen na malém počtu schválených návrhů a odpovědnost za legislativu měla téměř výhradně vláda.

Potud srovnání typických, dlouhodobých vzorců. Zaměŕíme-li pozornost na porovnávání lokálních, krátkodobých výkyvů, lze ve sledovaném období zachytit pozoruhodný trend: Pro vládu Vladimíra Špidly, Stanislava Grosse a Jiř́ho Paroubka (2002-2006) spolu (v menší míre) s druhou vládou Mirka Topolánka (2007-2009) a (ve větší míre) s vládou Petra Nečase (2010-2013) je typické to, že vykazují periody velice výrazného konfliktu, kdy došlo $\mathrm{k}$ dočasné, ale velmi silné polarizaci Sněmovny, tj. aktivizaci vlády a opozice. Vláda Petra Nečase se navíc vyznačuje výše zmíněnou obecně vysokou polarizací. Během těchto období se tedy oba bloky relativně silně snažily naplno využít svůj potenciál při protlačení, či naopak zablokování konkrétní série legislativních návrhů, poté se ale navrátily $\mathrm{k}$ ad-hoc režimu (u Nečasovy vlády k režimu omezené polarizace). 
Tyto konfliktní úseky se v relevantních obdobích koncentrují do hlasování o návrhu státního rozpočtu na následující rok (prosinec 2002, 2003, 2004, 2005; vše vlády ČSSD), a objevují se během hlasování o klíčových zákonech (vládní návrh zákona o DPH, únor 2004; Grossův kabinet), hlasování o Ústavu paměti národa (květen 2007), vyslání vojenských sil do Afghánistánu (duben 2008), hlasování o důchodovém a nemocenském pojištění (červen 2008, vše Topolánkův druhý kabinet). Lze je nicméně nalézt i při procedurálním a na první pohled „běžném“ hlasování, kde hrají úlohu strategickou nebo signalizační (směrem $\mathrm{k}$ voličům): Jde např. o období dlouhodobé aktivizace během vlády kabinetu Topolánek II při různých hlasováních (např̀. v červnu 2008). K velmi výrazným aktivizacím pak došlo vobdobí vlády kabinetu Nečas (setrvalá aktivizace v průběhu listopadu 2011 - procedurální hlasování, stavební spoření, veřejné zakázky aj., podobně od července do záŕí 2012 (novela ústavy, majetkové vyrovnání s církvemi, důchodové spoření, procedurální hlasovánî). Viz schémata 3 a 4 (výkyvy jsou podobné, ale celková tendence opozice je v př́padě Nečasova kabinetu i po zvážení jasně protivládní, zatímco vliv opozice za vlád ČSSD je spíše pozitivnî):

Schéma č. 3: Nárazově aktivizovaná Sněmovna jinak fungující v režimu ad-hoc: Vláda Vladimíra Špidly, Stanislava Grosse a Jiř́ího Paroubka.

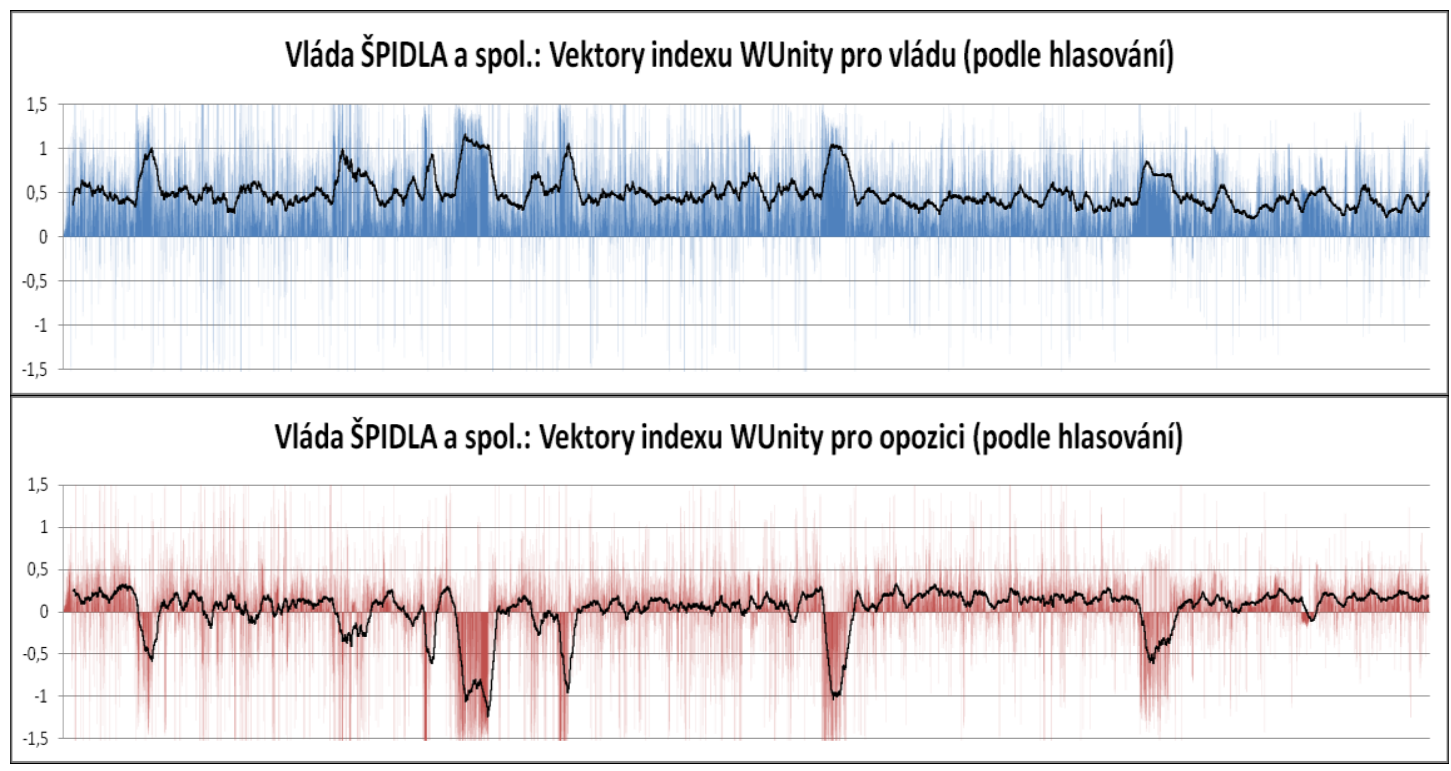


Schéma č. 4: Vysoce konfliktní střet vlády a opozice s dodatečnými výkyvy: Vláda Petra Nečase

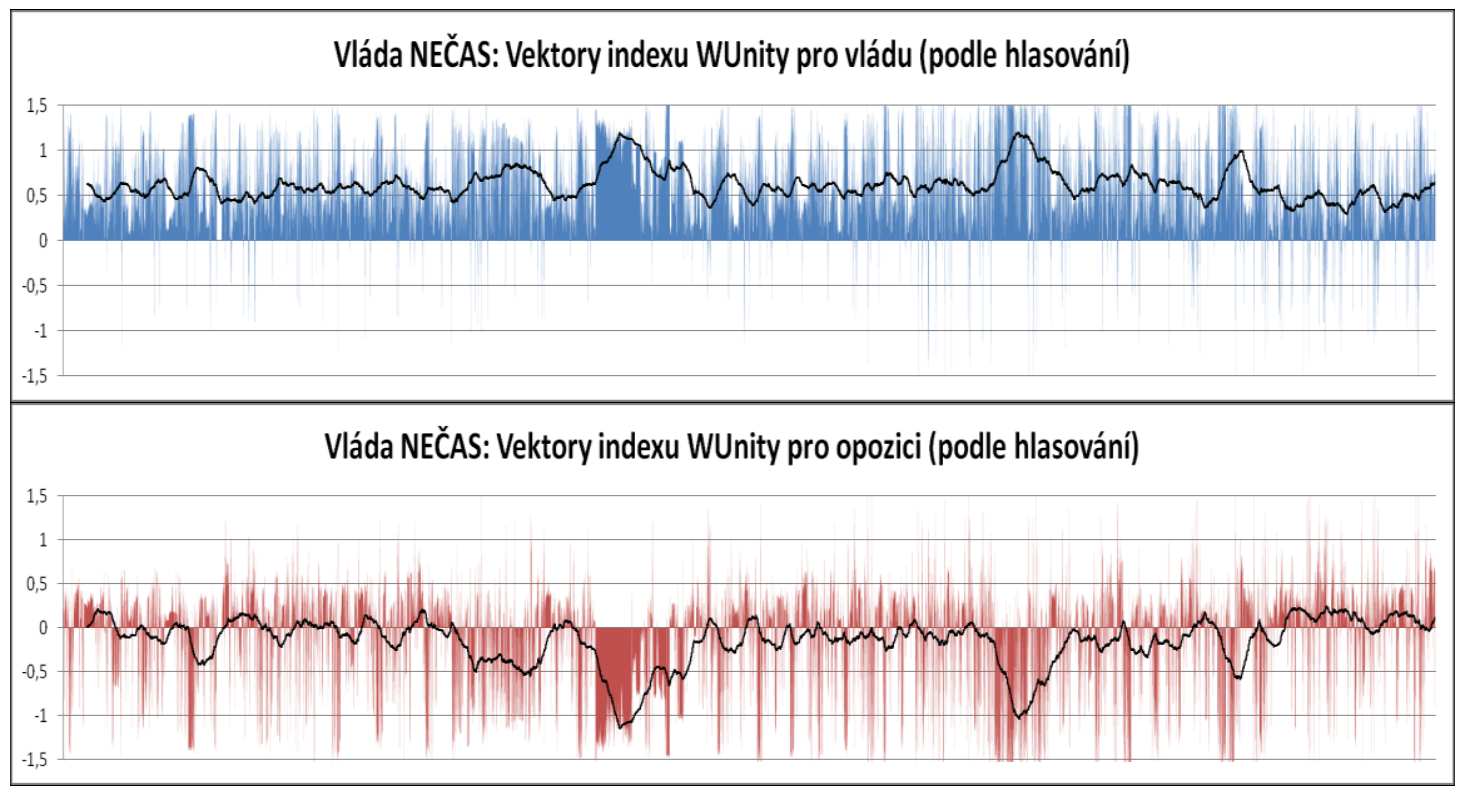

Z hlediska dlouhodobého vývoje od počátku devadesátých let po konec Nečasovy vlády tedy platí, že na jedné straně nelze identifikovat jednoznačný posun od spíše konsensuálního principu ke spíše konkurenčnímu (nebo jiný obdobný) - mnohem silnější roli hraje rozdělení na standardní, politické a na nestandardní, polopolitické kabinety, př́padně jejich jistota ve Sněmovně. Na druhé straně je dobře patrný přechod k výrazně koncentrovaněji jednajícím opozicím a rovněž změna stylu jednání Sněmovny: Pomineme-li úřednické kabinety, konflikt vlády a opozice ve Sněmovně do období vlády Miloše Zemana byl rozptýlený, zatímco kabinety, které př́šly po této vládě (od roku 2002), musely čelit odlišné strategii opozice, jež se vyznačovala časově omezenými obdobími konfliktu (intenzivní polarizace), při nichž (byt' nekoordinovaná a vždy vícestranická) opozice považovala za žádoucí hlasovat jednotně. Tato tendence vyvrcholila v období poslední analyzované vlády Petra Nečase, kde jednak došlo $\mathrm{k}$ intenzivním aktivizacím, jednak polarizace zůstávala mimořádně vysoká i v „klidných“ dobách. Povaha vztahu mezi koalicí a opozicí se tedy z dlouhodobého hlediska očividně proměnila - kompromis a potenciálně konstruktivní prrístup ke hlasování byl nahrazen př́stupem př́ležitostně konfliktním, založeným na dočasné mobilizaci a demonstraci jednoty.

Pokud se tedy vrátíme na začátek k rozlišení mezi smírlivou a konfrontační opozicí podle logiky Sylvie Giulj (1981), jejiž analytický rámec pro české prostř̌edí využili Michal Kubát (2010) i Jan Wintr (2010), z hlediska kvantitativních rozdílů v hlasování lze poměrně jasně definovat prèlom mezi fází spíše kooperativní 
a spíše konfliktní logiky, kterým je období kolem roku 2002, bezprostředně následující po konci „opoziční smlouvy.“ Tyto závěry tedy potvrzují předpoklad o výrazném vládně-opozičním konfliktu po roce 2002, zpřesňují jeho podobu (má na něj částečný vliv vzrůstající bloková jednota, ale především pak taktika sériového blokovánî). Naopak teze o změně práce parlamentu ve druhém období nebyla tak intenzivní, aby se projevila na vzorcích jednání koalice a opozice. ${ }^{16}$

\section{Závěry}

Předkládaná studie zkoumala behaviorální aspekt interakce mezi vládou a opozicí v české Poslanecké sněmovně a pokusila se o porovnání českých vlád v období 1993-2013 z hlediska míry konfliktnosti a jejího vývoje v čase. Její snahou prritom bylo překročit rámec široce definovaných kategorií (typicky jeden systém - jeden prrípad) a zaměřit se více na opomíjenou časovou dimenzi. Za použití předpokladu o vývoji demokratických institucí se zaměřila na konstrukci jednoduchého výzkumného rámce, který by umožňoval systematické srovnání dat týkajících se hlasování na dvou různých úrovních a který by bylo možné využít navzdory velmi omezeným informacím, které jsou v České republice k hlasování dostupné. Její zjištění jsou jak věcného, tak metodologického charakteru.

Z praktického hlediska práce na úrovni funkčních období nejen potvrdila intuitivní rozdíly (at' už jde o potvrzení pozice jednotlivých vlád nebo o rozdíl v převládajícím typu interakce mezi standardními a úřednickými vládami), ale přinesla i zpřesněný pohled na charakter vládně-opoziční interakce ve Sněmovně. Opozice ve druhé polovině období obecně fungovala o poznání koncentrovaněji než v první dekádě. Po započtení kritéria vlivu na hlasování (tj. souhlas versus nesouhlas s výsledkem) nelze říct, že by se opozice (kromě období úřednických kabinetů) pruiblížila dominanci nad vládní koalicí - spíše se zvýšila spolupráce $\mathrm{v}$ rámci opozičního tábora, resp. síly obou skupin se zkoncentrovaly a systém se více prriblížil logice dvou bloků. Především je zde patrný rozdíl mezi první a druhou polovinou zkoumaného období z hlediska krátkodobých ekvilibrií: U mladších vlád lze zaznamenat existenci konkrétních časových úseků (od nárazového hlasování o rozpočtu po setrvalejší obdobî), kdy při hlasování docházelo k obzvláštnímu vypětí opozice, které se zrcadlilo i v úsilí vládních stran. Nejvýraznější dočasné etapy konfliktu jsou pozorovatelné u kabinetů

\footnotetext{
${ }^{16}$ Je však třeba mít na paměti, že hlasování se v průběhu období koncentruje do relativně malého počtu hlasovacích dnů. Pokud za jednotku analýzy považujeme nap̌r. jeden měsíc, jedno čtvrtletí atd., a nikoli jedno hlasování, situace působí méně dramaticky. Po přepočtení na delší časové úseky grafy vykazují bud' nepravidelnou (u některých měření jednoty vlády versus opozice), př́padně setrvale klesající tendenci (u vybraných měření vláda versus opozice a téměř u všech měření dat na úrovni poslaneckých klubů). Tato možnost otevírá otázku převládajících typů, nejčastějších témat hlasování a vůbec rozložení legislativní práce v jednotlivých obdobích, které může mít dominantní vliv na to, jak zákonodárci jednají (srov. Crespin, Rohde a Vander Wielen 2011).
} 
Špidla/Gross/Paroubek, Topolánek II a Nečas. V dalších vybraných obdobích je odpor opozice spíše rozptýlený než koncentrovaný a hlasování se řídí spíše ad-hoc logikou (kabinety Klaus II, Zeman). V ostatních př́padech jde o kabinety, které povolily (resp. byly nuceny povolit) jistou míru konsensuální praxe při hlasování. Systematický přístup ke komparaci kabinetů dále zvýraznil některé zajímavosti, jako např. fungování kabinetů Klaus II a Topolánek II, vymykající se do jisté míry typu koalice, nebo poměrně výrazné rozdíly mezi jednotlivými úřednickými vládami. Díky vlastnostem indexu UNITY byla také identifikována typická hlasování, na kterých se opozice nejvíce profilovala. Šlo zejména o ekonomická témata, ale i o hlasování týkající se zahraničních misí nebo vztahu $\mathrm{k}$ minulosti. Není bez zajímavosti, že výraznější polarizující výkyvy jsou patrné u nedávných vlád (Špidla a spol., Topolánek II, Nečas), tj. u všech kabinetů s výjimkou úřednických, které následovaly po období „opoziční smlouvy“. Oproti tomu hlasování vobdobí prvních čtyř kabinetů (od vlády Klaus I až po vládu M. Zemana) bylo výrazně klidnější. Došlo tedy $\mathrm{k}$ proměně vzorců opozičního jednání, resp. ke změně podoby střetu v Poslanecké sněmovně směrem od konstruktivnější k razantnějšśi, blokační strategii, takže byla posílena logika dvou bloků a „hry s nulovým součtem“. Tento přechod se shoduje s posunutím českého př́ipadu směrem $\mathrm{k}$ větší konfliktnosti stranického systému a současně k menší stabilitě vlád (srov. Wintr 2010; Havlík 2011: 81).

Otázkou je, jak tuto všeobecnou proměnu interpretovat - může jít o projev konsolidace stranických pozic stejně jako o projev krize ve smyslu vyčerpání dosavadní relativně konstruktivní praxe. Jan Wintr vysvětluje změny v práci Sněmovny mj. idiosynkratickými faktory, jako byla skladba projednávané agendy. V tomto ohledu bylo význačné páté období, které príneslo debaty o konfliktních tématech, jako byla radarová základna USA v ČR, otázka regulačních poplatků ve zdravotnictví atd. Dalšími milníky ve vývoji vládně-opozičních vztahů byly napr. přechod poslanců $\mathrm{k}$ využívání taktiky osočení z korupce a dalších nelegálních činů jako standardního nástroje politických debat nebo počátek využívání návrhu na vyslovení nedůvěry vládě v době vlády $\mathrm{S}$. Grosse. $\mathrm{Na}$ druhou stranu i starší období měla své zdroje polarizace, např. př́tomnost radikální SPR-RSČ ve Sněmovně v první polovině devadesátých let (Wintr 2010). Institucionální faktory podobné vysvětlení nenabízí. Ačkoli na výsledky má napríklad přirozeně vliv, s jakou jistotou mohly vlády počítat s většinou ve sněmovně, nelze ř́íci, že by umístění kolem výsledné prrímky bylo prostou funkcí velikosti vládní většiny. Otázka vlivu typu vládní koalice na způsob interakce je také nejednoznačná: $\mathrm{Na}$ jednu stranu při porovnání průměrných hodnot vycházejí minimálně vítězné kabinety jako obecně konfliktnější (výraznou výjimkou byl ale druhý, menšinový, Klausův kabinet). Na druhé straně je vztah komplikován přechodem k aktivizaci opozice po roce 2002 - ta se objevuje videově propojených i ideově nepropojených kabinetech. Navíc platí, že Topolánkův druhý kabinet, technicky vzato menšinový, se vyznačoval silnou tendencí k sériovému blokování a naopak 
minimálně vítězný ideově propojený první Klausův kabinet je dobrým př́kladem hlasování ad-hoc. Otázka konfliktu v Poslanecké sněmovně tedy rozhodně není jednorozměrná, což je do jisté míry dáno už nemožností vysledovat převažující typ koalic nebo stabilnějš́i interakce $\mathrm{v}$ rámci stranického systému (srov. Havlík 2011: 72-75).

Český př́pad je vůbec jedním $z$ těch, kde interpretace dat nemůže být př́močará, zejména vlivem existence neformálních mechanismů ve Sněmovně. I když by se už sama přetrvávající existence párování dala interpretovat jako důkaz relativně snížené konkurence, posun klogice aktivizace a vzrůstající počet absolutně jednotných hlasování je nicméně velmi výrazný. Tendence ke konfliktnímu jednání stoupá a Sněmovna se tak více přibližuje logice vláda versus opozice. Logika práce Sněmovny tedy v tomto směru (snad kromě tzv. období nulové tolerance) vykazuje určitý paradox a naznačené změny ve vztazích mezi aktéry na každý pád zůstávají důležitým tématem pro podrobnější výzkum.

Z metodologického hlediska platí, že navzdory neformálním dohodám o nehlasování jsou rozdíly mezi jednotlivými obdobími jednoznačné - vliv párování je tedy omezený a neznemožňuje využití indexu UNITY. Nástroje tento ukazatel využívající tudíž nemají v českém případě a při tomto typu aplikace výrazně sníženou rozlišovací schopnost, resp. vliv párování je na celkové výsledky slabší než vliv ostatních faktorů. S ohledem na koncentrovanost a konfliktnost hlasování neexistují mezi variantami indexů Rice a Rice2, resp. UNITY a UNITY2 výraznější rozdíly. Platí ale, že použití „českých“ variant je metodologicky zodpovědnější. Práce $s$ novějšími indexy na nižší úrovni (s využitím časových řad) může navíc dobře odlišit konfliktní hlasování od nedůležitých a ukázat tak na mnohdy výrazné rozdíly mezi kabinety, které by při běžném jednoduchém srovnání mohly zůstat skryty (UNITY např́ílad dokáže vizualizovat proměnlivost koncentrovanosti hlasování i tehdy, pokud je Riceův index konstantně téměř stoprocentnî). Index UNITY Johna Careyho se tedy přes všechny své limity v této analýze ukázal být užitečným nástrojem, protože umožnil vizualizovat proměnlivost působení vlády a opozice v čase. Jeho aplikace si však přirozeně žádá obezřetnost, protože zvýšená citlivost tohoto nástroje ve srovnání se starším ukazatelem znamená i vyšší nároky na použití. Bližší analýza jednotlivých rozdílů mezi jednotlivými technikami je dalším námětem pro budoucí výzkum, celkově je však možné prohlásit, že obraz, který lze získat z tak minimalistických vstupních informací, jako je prostá informace o hlasech jednotlivých poslanců spojená se znalostí výsledku hlasování, je pozoruhodně plastický a kompatibilní s informacemi získanými jinými metodami. Ačkoli do určité míry zatím pouze potvrzuje intuitivní závěry, využití těchto technik a jejich spojení s dalšími metodami může $\mathrm{v}$ budoucnu přinést zajímavé plody.

I využití časové dimenze hlasování se zdá být jednou z vhodných cest, jak rozšíríit dosavadní způsoby komparace. Ohled na proměnlivost situace přináší podrobnější náhled na fungování parlamentu ve srovnání s prostým sledováním 
průměrných hodnot. V budoucnu by tato analýza mohla být doplněna o další nástroje. Jako potenciálně užitečné se jeví např́klad odlišení hlasování o finálních návrzích a typů hlasování vůbec. To je v současnosti závislé především na kvalitě dat, např́klad v českém případě jej zatím nelze jednoduše dosáhnout bez časově téměř neproveditelného ručního třídění záznamů. Znalost podrobnějších parametrů hlasování by mohla analýzu posunout do roviny debaty o charakteru platné legislativy nebo o prioritách jednotlivých vlád (srov. Döring 2001; Crespin, Rohde a Vander Vielen 2011 aj.). Měření aktivity v parlamentu může být jednou $z$ alternativních možností, kudy se vydat při řešení otázky, jak snadno identifikovat důležitá hlasování a klíčová témata $\mathrm{v}$ případě, kdy jednotlivé záznamy nelze snadno odlišit filtrováním. $V$ neposlední řadě je přirozeně třeba zaměřit pozornost na co nejširší spektrum demokratických politických systémů a zjistit, jak se situace liší $\mathrm{v}$ různých prostředích. I tyto pokusy však budou závislé především na dostupnosti a kvalitě dat. Omezenost dat z různých institucí bohužel stále zůstává nejvýraznější př̀kážkou studia legislativního jednání.

\section{Bibliografie}

Borz, Gabriela (2006): "Determinants of Party Unity in Central Eastern Europe." CEU Political Science Journal 2006(3): 29-48.

Bowler, Shaun, David M. Farrell a Richard. S. Katz (1999): Party Discipline and Parliamentary Government. Columbus: Ohio State University Press.

Bütikofer, Sarah a Simon Hug (2008): "Strategic behavior in the Swiss parliament." Paper presented at the Annual Meeting of the American Political Science Association, Boston, August 2008, on-line (http://www.unige.ch/ses/spo/static/simonhug/sbisp/sbisp. pdf) [cit. 13. 2. 2014].

Carey, John M (2000): "Party Unity in Legislative Voting." Presentation at American Political Science Associations Conference, Washington, September 2000, on/line (http://www.researchgate.net/publication/2412757_Party_Unity_in_Legislative_Votin g/file/9c9605293d09ea8e1b.pdf) [cit. 13. 2. 2014].

Carey, John M (2007): "Competing Principals, Political Institutions, and Party Unity in Legislative Voting." American Journal of Political Science 51(1): 92-107, http://dx.doi.org/ 10.1111/j.1540-5907.2007.00239.x.

Carey, John M. (2009): Legislative Voting and Accountability. New York: Cambridge University Press.

Colomer, Josep M. (2001): Political Institutions. Democracy and Social Choice. New York: Oxford University Press.

Crespin, Michael H., David W. Rohde, and Ryan J. Vander Wielen (2013): „Measuring Variations in Party Unity Voting: An Assessment of Agenda Effects." Party Politics 19(3): 432-457, http://dx.doi.org/10.1177/1354068811407578.

Dahl, Robert A. (ed.) (1965): Political Oppositions in Western Democracies. New Haven: Yale University Press.

Döring, Herbert (ed.) (1995): Parliaments and Majority Rule in Western Europe. Mannheim: MZES. 
Duverger, Maurice (1965): Political Parties. Their Organization and Activity in the Modern State. New York: John Wiley \& Sons.

Ferejohn, John (1999): “Accountability and Authority: Toward a Theory of Political Accountability." In: Adam Przeworski, Susan C. Stokes, and Bernard Manin (eds.). Democracy, Accountability, and Representation. Cambridge: Cambridge University Press, 131153.

Fortes, Braulio G. a Irene P. Brihuega (2012): "Testing the quality of democracy: The case of Spain." European Political Science 11(4): 492-508, http://dx.doi.org/10.1057/ eps.2011.48.

Giebler, Heiko (2012): "Bringing Methodology (Back) in: Some Remarks on Contemporary Democacy Measurements." European Political Science 11(4): 509-518, http://dx.doi.org/10.1057/eps.2011.47.

Giulj, Sylvie (1981): "Confrontation or Conciliation: the Status of the Opposition in Europe." Government and Opposition 16(4): 476-494, http://dx.doi.org/10.1111/j.14777053.1981.tb00324.x.

Golombiewski, Robert T. (1958): “A Taxonomic Approach to State Political Party Strength." Western Political Quarterly 11: 390-420.

Gregor, Kamil a Vlastimil Havlík (2013): „Příčiny jednotnosti hlasování a složení legislativních koalic v Senátu ve srovnání s Poslaneckou sněmovnou v letech 19982010.“ Sociologický ćasopis 49(4): 549-576.

Havlík, Vlastimil (2011): „Česká republika.“ In: Stanislav Balík, Vlastimil Havlík et al., Koalični vládnuti ve strední Evropě (1990-2010). Brno: Masarykova univerzita, 39-90.

Hix, Simon a Abdul Noury (2011): "Government-Opposition or Left-Right? The Institutional Determinants of Voting in Legislatures" Working Paper, on-line (http://personal.lse.ac.uk/hix/Working_Papers/Hix-Noury-GOorLR-07Mar2013.pdf) [cit. 13. 2. 2014].

Hloušek, Vít a Lubomír Kopeček (2012): Záchrana státu? Úrednické a polopolitické vlády $v$ Ceské republice a Ceskoslovensku. Brno: Barrister \& Principal.

Kubát, Michal (2010): Politická opozice v teorii a středoevropské praxi (vybrané otázky). Praha: Dokořán.

Kysela, Jan (2003): "Poslanecká sněmovna v ústavním systému České republiky" In: Lukáš Linek et al (eds.). Volby do Poslanecké snémovny v roce 2002. Praha: Sociologický ústav Akademie věd ČR, 2-16.

Kysela, Jan (2008): „Parlament a parlamentarismus.“ In: Jindřriška Syllová et al. (eds.). Parlament Ceské republiky. Praha: Linde, 16-49.

Lijphart, Arend (1984): Democracies: Patterns of Majoritarian and Consensus Government in Twenty-One Countries. New Haven: Yale University Press.

Lijphart, Arend (1999): Patterns of Democracy: Government Forms and Performance in Thirty-Six Countries. New Haven: Yale University Press.

Lyons, Pat, Tomáš Lacina (2009): "An Examination of Legislative Roll-Call Voting in the Czech Republic Using Spatial Models.” Sociologický ćasopis / Czech Sociological Review 45(6): 1155-1190.

Mair, Peter (2011): Ruling the Void. The Hollowing of Western Democracy. London: Verso.

Mansfeldová, Zdenka (2005): "Executive-Legislative Relations in the Budgeting Process in the Czech Republic.” Sociologický časopis / Czech Sociological Review 41(3): 443-460. 
Munck, Gerardo L. (2009): Measuring Democracy. A Bridge between Scholarship and Politics. Baltimore: The John Hopkins University Press.

Novák, Miroslav (1997): Systémy politických stran. Úvod do jejich srovnávacího studia. Praha: Sociologické nakladatelství.

Novák, Miroslav (2001): Jakou demokracii pro nové demokracie? Brno: Masarykova univerzita, Mezinárodní politologický ústav.

O’Donnell, Guillermo (1991): “Delegative Democracy? East-South System Transformations.” Working paper. Chicago: University of Chicago.

O’Donnell, Guillermo (1998): "Horizontal accountability in New Democracies." Journal of Democracy 9(3): 112-126, http://dx.doi.org/10.1353/jod.1998.0051.

Ozbudun, Ergun (1970): Party Cohesion in Western Democracies: A Casual Analysis. Beverly Hills: Sage Books.

Paskalev, Vesselin (2002): "Institutionalization of Parliamentary Control over the Administration. The House of Commons Select Commities in Comparative Perspective." LLM Thesis. Budapest: Central European University, on-line (http://www.academia.edu/779351/INSTITUTIONALIZATION_OF_PARLIAME NTARY_CONTROL_OVER_THE_ADMINISTRATION) [cit. 13. 2. 2014].

Prata, Adriana (2006): "Government Domination, Consensus or Chaos? A Study of party Discipline and Agenda Control in National Legislatures [online]." Dissertation thesis. San Diego: University of California, on-line (https://escholarship.org/uc/item/ 8db7g012\#page-1) [cit. 13. 2. 2014].

PSP ČR (2014): Data Poslanecké sněmovny a Senátu. Odbor informatiky Kanceláře Poslanecké sněmovny, on-line (http://www.psp.cz/sqw/hp.sqw?k=1300 [cit. 13. 2. 2014].

Rice, Stuart A. (1925): "The Behavior of Legislative Groups: A Method of Measurement." Political Science Quarterly 40(1): 60-72, http://dx.doi.org/10.2307/ 2142407.

Sieberer, Ulrich (2006): "Party Unity in Parliamentary Democracies: A Comparative Analysis." The Journal of Legislative Studies 12(2): 150-178, http://dx.doi.org/10.1080/ 13572330600739413.

Skjæveland, Asbjørn (1999): “A Danish Party Cohesion Cycle." Scandinavian Political Studies 22(2): 121-136, http://dx.doi/10.1111/1467-9477.00008.

Stokes, Susan C. (1999): "What Do Policy Switches Tell Us about Democracy?" In: Adam Przeworski, Susan C. Stokes a Bernard Manin (eds.): Democracy, Accountability, and Representation. Cambridge: Cambridge University Press, 98-130.

Wintr, Jan (2010): Ceská parlamentní kultura. Praha: Auditorium.

\section{Adversary Voting in the Czech Chamber of Deputies (1993-2013) SUMMARY}

The paper is an explorative case study of the concentration / legislative unity of government and opposition blocs in the Chamber of Deputies, a key legislative institution in the Czech Republic, over a period of twenty years (i.e. six legislative or nine government terms). The general theoretical context of the study is the "Westminster 
versus consensual democracy" model dating back to Arend Lijphart's works. According to this model, Westminster democracies are supposed to feature government dominance and open political rivalry, whereas the consensual kind are associated with compromise building and the tendency to neutralise political conflict. As for government-opposition relations, pure Westminster or consensual democracies do not exist today; the situation tends to be dynamic and context-dependent. In legislatures, voting may be regarded as conflictual when it works as a zero-sum game (i.e. parties vote in a concentrated way and explicitly against each other). As voting unity is usually rather low in the Czech Republic (and elsewhere), highly unified votes may be regarded as exceptional cases linked to a higher bloc concentration, and therefore the higher importance of a vote and a higher rate of conflict, as is apparent from preliminary data analyses. The Czech Republic, a post-communist CEE democracy, is an obvious case for the application of the "stabilisation hypothesis" (which argues that the actors and institutions change as the rules of the game settle after the transition to democracy). Indeed, some accounts of the change in the way the Parliament works in the Czech Republic have been elaborated. These were based on a historiographical, qualitative approach. The question of this study, however, is whether the change is distinctive enough to be detected using descriptive statistics.

The study focuses on one of the most important dimensions of voting, the "government versus opposition" dimension. It investigates the behavioural aspect of political conflict (rather than formal institutional rules), and it does so with the focus on raw, non-aggregated parliamentary voting data in order to distinguish between individual terms and even shorter periods of time. As such, it tries to answer calls for lower-level analyses which are supposed to yield more detailed information than traditional comparisons of average, highly aggregated values (based on the "one system - one case" logic) while also retaining the advantages of exact quantitative methods. I use Stuart Rice's classic index along with John Carey's novel UNITY index to compare average unity scores of individual government and opposition blocs; afterwards, I use an explorative framework based on time series of unity vectors to analyse bloc unity and bloc success rate in order to identify periods of typical versus exceptional conflict (hence "polarity vectors"). This framework is based on the time-series analysis in which each vote is one data point. Compared to the use of simple (average) unity scores, the framework incorporates both the spatial criterion (as a timeline of won versus lost votes for both blocs analysed) and the dimension of time (an analysis of usual legislative operation versus periods of the unusual activation of both blocs, which is linked to higher interaction conflict). Due to its different approach to counting abstentions and nonvoting, the UNITY index has a potential to discover more nuanced differences when considering the use of legislative potential rather than internal cohesion. On the other hand, it is too sensitive to informal agreements in the legislature; thus, it has to be used with caution and with regard to the context.

The outcomes of the analysis are twofold: practical and methodological: As for practical findings, although there are interesting variations between cases, broad differences in the logic of interaction are confirmed (e.g. all caretaker cabinets show less conflict than standard cabinets). On the one hand, although oppositions after 2002 evidently became "stronger" (more concentrated), no major linear, universal trend is found when one focuses on mutual differences between the cabinets, incorporating the 
criterion of won and lost votes (for example, there is no clear transition from consensual to conflictual practice, as indicated by a possible interpretation of the "stabilisation hypothesis"). On the other hand, an observable change in legislators' behaviour and the government-opposition dynamic did occur after all, albeit on a lower level. Unlike in the first decade, the Czech opposition resorted to the tactics of serial blocking, i.e. blocking whole series of votes after 2002 - a phenomenon which had not existed before the period of the "Opposition Agreement" at the turn of the new century. This change of tactics and style might be mapped to the transition between two types of opposition, as suggested by Sylvie Giulj (cooperating versus adversary practice), because the change was strong enough to alter the structure of unity vector timelines. The last cabinets analysed are the clearest examples of this conflictual practice combined with a significant transition to the logic of government-opposition conflict.

As for methodological observation, the relative differences found are highly analogous for both the Rice and UNITY indices, which is not a surprise with regard to the fact that both indices correlate significantly. This means that UNITY's discrimination capacity is not heavily distorted as might sometimes be the case with the Rice index (because the existence of an informal agreement may be found in the Chamber, a phenomenon to which the UNITY index is particularly sensitive). This practice, called "pairing", consists in occasional mutually-arranged non-voting equilibria between individual members of the government coalition (who cannot be present in the Chamber during the vote) and their opposition counterparts. Moreover, when used correctly, the UNITY index is able to distinguish important votes which are not detectable by the Rice index alone and, thus, it is a valid addition to the analysis of less-aggregated and nonaggregated data. Information gained in this way would normally be hidden behind average, highly aggregated scores. In other words, provided the risks are sufficiently analysed in advance and the tool is used with caution, it may be useful in revealing a more vivid, more detailed picture of the institution analysed. 